\title{
2,4-Distyryl- and 2,4,6-tristyrylpyrimidines: Synthesis and photophysical properties.
}

Michaela Fecková, ${ }^{\dagger, \star}$ Pascal le Poul,${ }^{\dagger}$ Françoise Robin-le Guen, ${ }^{\dagger}$ Thierry Roisnel, ${ }^{\dagger}$ Oldřich

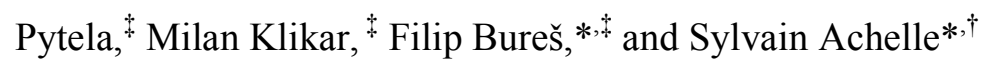

${ }^{\dagger}$ Univ Rennes, CNRS, ISCR (Institut des Sciences Chimiques de Rennes) - UMR 6226, F35000 Rennes, France. ${ }^{\star}$ Institute of Organic Chemistry and Technology, Faculty of Chemical Technology, University of Pardubice, Studentská 573, Pardubice, 53210, Czech Republic.

Corresponding authors: *E-mails: sylvain.achelle@univ-rennes1.fr; filip.bures@upce.cz

\section{Synopsis TOC}

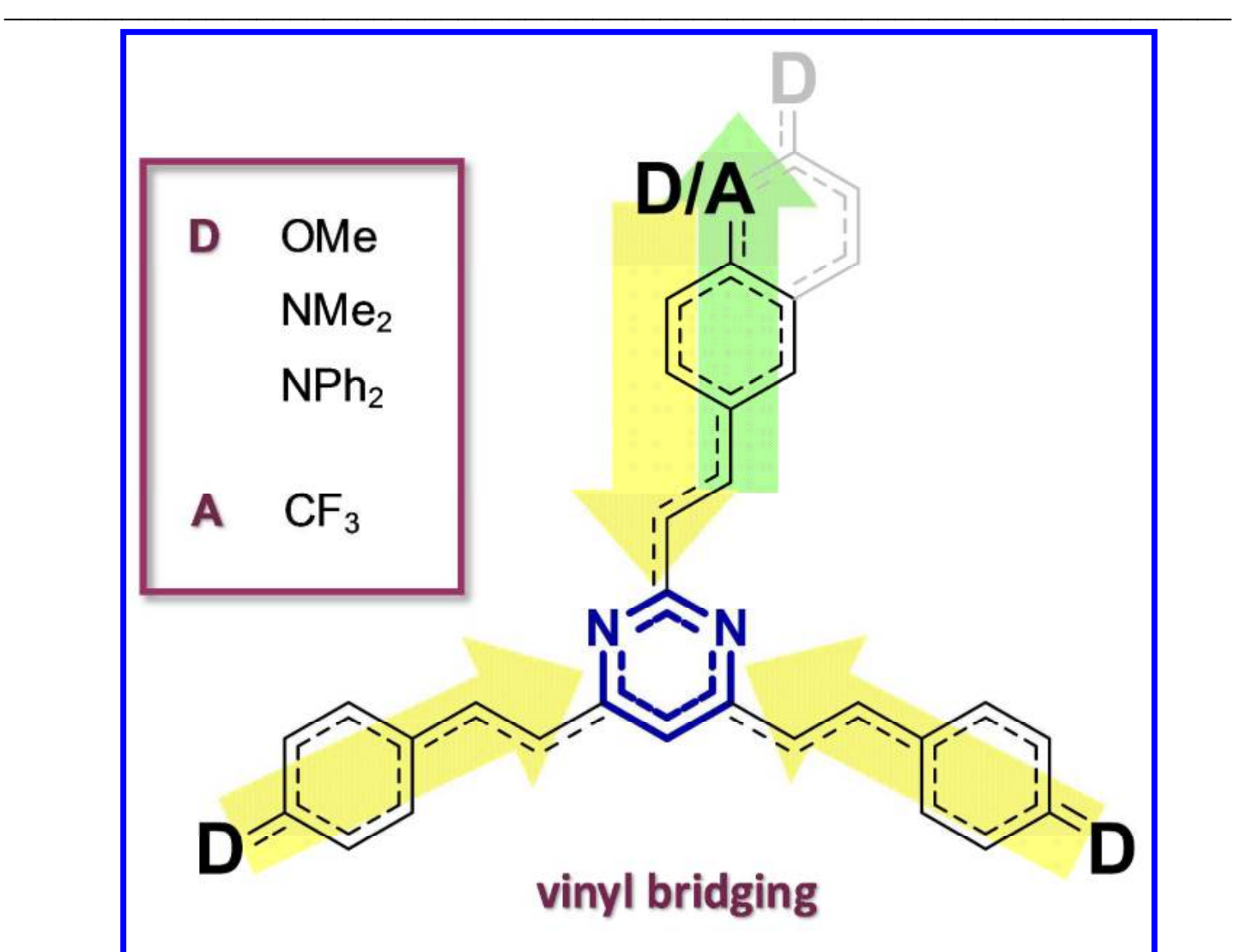

\section{Abstract}


The synthesis of a series of twenty new 2,4,6-tristyrylpyrimidines and three new 2,4distyrylpyrimidines by means of combination of Knoevenagel condensation and SuzukiMiyaura cross coupling reaction is reported. This methodology enables to obtain chromophores with identical or different substituent on each arm. The photophysical properties of the compounds are described. Optical properties and TD-DFT calculations indicate that photophysical properties of target compounds are mainly affected by the nature of the electron-donating group in $\mathrm{C} 4 / \mathrm{C} 6$ positions, except when the $\mathrm{C} 2$ substituent is a significantly stronger electron-donating group. However, the $\mathrm{C} 2$ substituent has a strong influence on emission quantum yield: addition of a strong electron-donating group tends to decrease the fluorescence quantum yield whereas a moderate electron-withdrawing group results in a significant increase of fluorescence quantum yield.

\section{Introduction}

During the past two decades, there has been a great interest in the synthesis of pyrimidine fluorophores. ${ }^{1}$ The pyrimidine is a six-membered heterocycle with two nitrogen atoms (1,3-diazine) that exhibits a strong electron-withdrawing character. When the pyrimidine ring is combined with electron-donating fragments via $\pi$-conjugated linkers, intramolecular charge transfer (ICT) occurs leading, generally, to a strong emission. ${ }^{1}$ Recently, pyrimidine-based thermally activated fluorescent emitters (TADF) have been developed and have been used for high external quantum efficiency organic light-emitting diodes (OLEDs). ${ }^{2}$ 4,6-Distyrylpyrimidines have also been developed as two-photon excitation emitters for biological microscopy ${ }^{3}$ and photoinitiator for multiphoton lithography. ${ }^{4}$

Due to the electron lone pair of its two nitrogen atoms, the pyrimidine ring can catch protons, coordinate metal cations, and link to various (bio)organic molecules leading to modification of its emission properties. Various pyrimidine chromophores have been used as $\mathrm{pH},{ }^{5}$ metal 
cations, ${ }^{6}$ nitroaromatic ${ }^{7}$, and protein $^{8}$ fluorescent sensors. Mixtures of neutral and protonated forms of pyrimidine fluorophores have also been used as white light emitters. ${ }^{9}$ Recently, Kato and coworkers have highlighted the influence of substituent in $\mathrm{C} 2$ position on the emission properties of pyrimidine derivatives. ${ }^{10}$

Y-shaped centripetal molecules have been subject to intensive research. ${ }^{11}$ In this context, the triazine core has been extensively used. ${ }^{12}$ In these structures, periphery-to-core multidimensional charge transfer lead to large second-order optical response ${ }^{13}$ and large two photon absorption cross section. 14 Numerous 2,4,6-triaryl- and 2,4,6triarylethnynylpyrimidine chromophores have been designed for their luminescence properties. $^{15,16}$

Styrylpyrimidines are generally obtained by Knoevenagel condensation of an aldehyde with methylpyrimidine under basic or acidic conditions. ${ }^{4,5,8,9 a, 10,17}$ This reaction can be easily carried out on the methyl group in positions C2, C4 and/or C6. Using this strategy, 2-styryl, ${ }^{18}$ 4-styryl ${ }^{3 \mathrm{c}, 9 \mathrm{a}, 17}$ and 4,6-distrylpyrimidine $\mathrm{e}^{3,4,5 \mathrm{a}, 8,10,17}$ as well as 4,4',6,6'-tetrastyrylpyrimidine ${ }^{19}$ chromophores have been prepared so far; selected known 4,6-distyrylpyrimidines are presented in Chart 1. To the best of our knowledge, only the unsubstituted 2,4,6tristyrylpyrimidine has been described to date. ${ }^{20}$

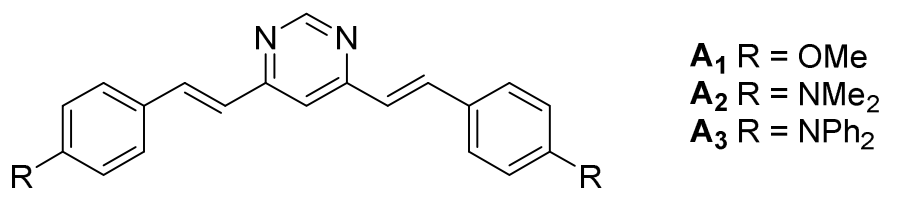

Chart 1. Structures of selected known chromophores 4,6-distyrylpyrimidines. ${ }^{5 a, 17 a}$

In this contribution, we describe the design and synthesis of 2,4,6-tristyrylpyrimidines and 2,4-distyrylpyrimidines by combining Suzuki-Miyaura cross coupling reaction and Knoevenagel condensation. This strategy enables the synthesis of compounds with different substituents on each arm and, thus, allows modification of their electron donating or withdrawing abilities. The molecular structure obtained by X-ray analysis of a selected 
chromophore is also described. The photophysical properties of target chromophores were studied and thoroughly compared with the corresponding 4,6-distyrylpyrimidines. The DFT and TD-DFT calculations were also performed on selected chromophores to rationalize their photophysical properties.

\section{Results and discussion}

\section{Synthesis}

Various strategies have been considered for the synthesis of 2,4,6-tristyrylpyrimidines. Threefold Knoevenagel condensation from 2,4,6-trimethylpyrimidine has been envisioned. However, the pyrimidine starting material cannot be isolated easily in a good yield. ${ }^{21}$ The synthesis of 2-methyl-4,6-distyrylpyrimidine was also considered by treating 4,6distyrylpyrimidine with methyllithium followed by in-situ rearomatization with DDQ according to known procedure ${ }^{22}$ but we failed in obtaining the desired product. We therefore proposed a third strategy, starting from commercially available 2-chloro-4,6dimethylpyrimidine and 2,4-dichloro-6-methylpyrimidine. A combination of Suzuki crosscoupling and Knoevenagel condensation has been developed leading to twenty-one tristyrylpyrimidine chromophores (Schemes 1-2).

Chromophores 2 with identical substituents in C4 and C6 positions were obtained in two steps from 2-chloro-4,6-dimethylpyrimidine. The first step consists of the in-situ conversion of arylalkynes into styrylboronic acid by action of catecholborane followed by palladiumcatalyzed Suzuki-Miyaura cross coupling reaction. ${ }^{23}$ 2-Styrylpyrimidine intermediates 1 were obtained in moderate to good yields. 2,4,6-Tristyrylpyrimidines 2 were obtained by condensation between the C4 and C6 methyl group and the corresponding aromatic aldehyde in boiling aqueous $5 \mathrm{M} \mathrm{NaOH}$ using Aliquat 336 as catalyst. ${ }^{5 a, 17 a}$ Moderate to good yields 
were generally observed. The lower yields, observed in particular for unsubstituted styryl derivatives, were due to more complicated purification process.

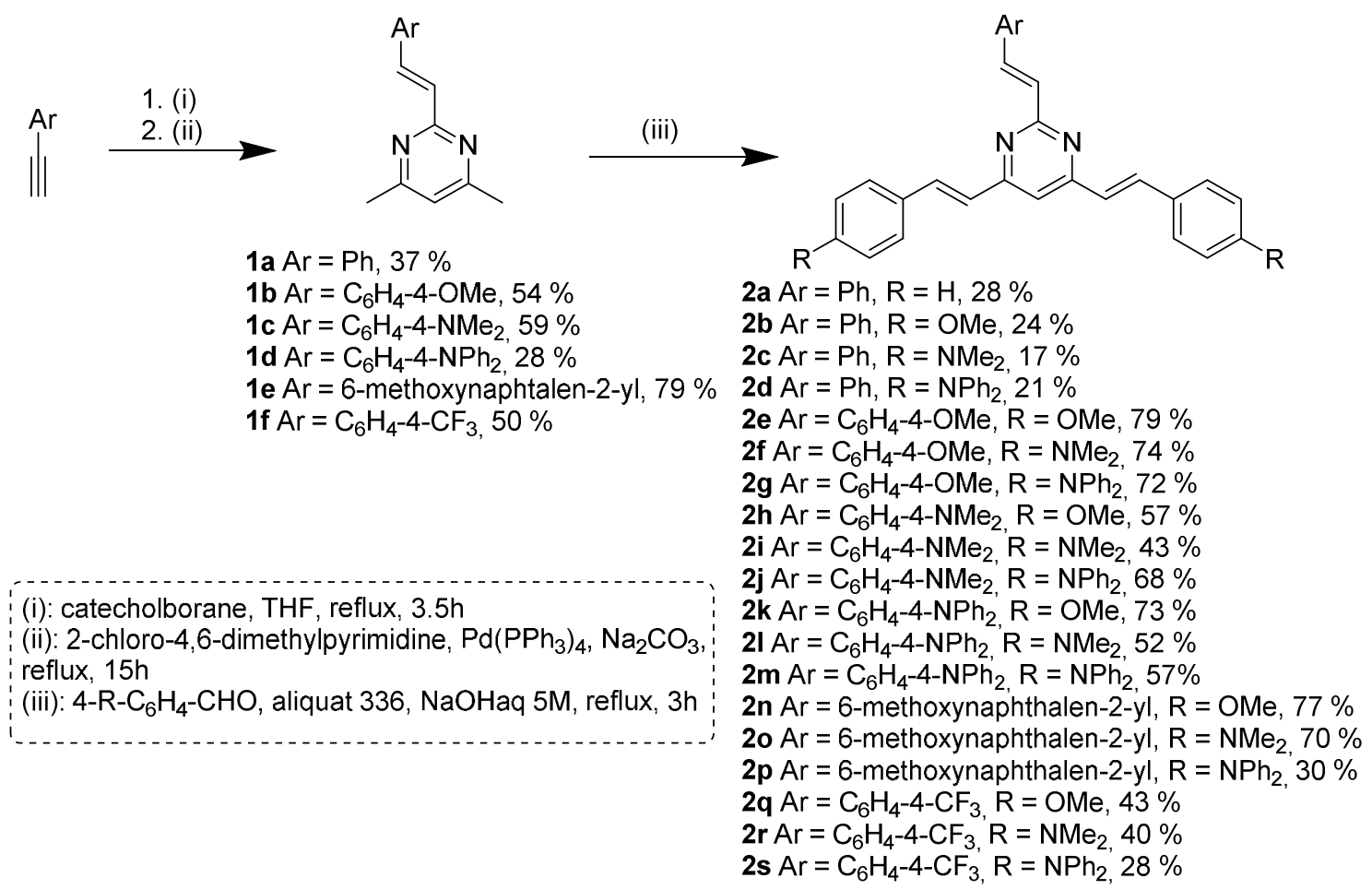

Scheme 1: Synthesis of compounds 2.

To obtain 2,4,6-tristyrylpyrimidines 5 with three different arms, a three-step synthetic route employed 2,4-dichloro-6-methylpyrimidine as a starting material (Scheme 2). The first step consisted in a C4 regioselective Suzuki-Miyaura cross coupling reaction with in situ formed styrylboronic acid leading to intermediates 3 . The observed regioselectivity of cross coupling reaction in $\mathrm{C} 4$ over $\mathrm{C} 2$ position of the pyrimidine ring is in accordance with the literature. ${ }^{15 b, 16 a, 24}$ The second step consisted in a second Suzuki-Miyaura cross coupling reaction in $\mathrm{C} 2$ position leading to 2,4-distyrylpyrimidines intermediates 4 and finally a Knoevenagel condensation of 4-( $N, N$-diphenylamino)benzaldehyde on the methyl group in C6 position lead to chromophores $\mathbf{5}$. 

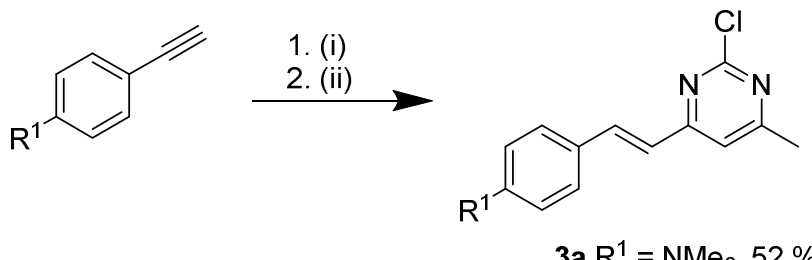

$3 b \mathrm{R}^{1}=\mathrm{OMe}, 55 \%$
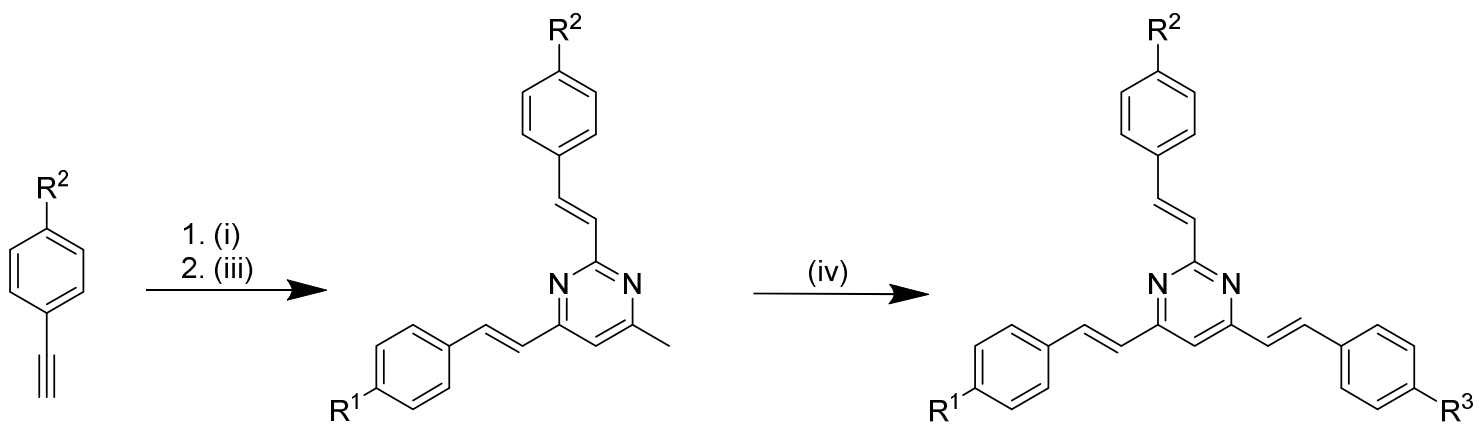

4a $\mathrm{R}^{1}=\mathrm{NMe}_{2}, \mathrm{R}^{2}=\mathrm{OMe}, 40 \%$

5a $\mathrm{R}^{1}=\mathrm{NMe}_{2}, \mathrm{R}^{2}=\mathrm{OMe}, \mathrm{R}^{3}=\mathrm{NPh}_{2}, 61 \%$

4b $R^{1}=\mathrm{OMe}, \mathrm{R}^{2}=\mathrm{NMe}_{2}, 75 \%$

5b $R^{1}=\mathrm{OMe}, \mathrm{R}^{2}=\mathrm{NMe}_{2}, \mathrm{R}^{3}=\mathrm{NPh}_{2}, 33 \%$

(i): catecholborane, THF, reflux, $3.5 \mathrm{~h}$

(ii): 2,4-dichloro-6-methylpyrimidine, $\mathrm{Pd}\left(\mathrm{PPh}_{3}\right)_{4}, \mathrm{Na}_{2} \mathrm{CO}_{3}$, reflux, $15 \mathrm{~h}$

(iii): $\mathbf{3 a}$ or $\mathbf{3 b}, \mathrm{Pd}\left(\mathrm{PPh}_{3}\right)_{4}, \mathrm{Na}_{2} \mathrm{CO}_{3}$, reflux, 15h

(iv): $4-\mathrm{R}^{3}-\mathrm{C}_{6} \mathrm{H}_{4}-\mathrm{CHO}$, aliquat $336, \mathrm{NaOHaq} 5 \mathrm{M}$, reflux, $3 \mathrm{~h}$

Scheme 2: Synthesis of compounds 5.

Starting from 2-chloro-4-methylpyrimidine, 2,4-distyrylpyrimidines were obtained in a similar two-step synthetic pathway (Scheme 3). 
(i): catecholborane, THF, reflux, $3.5 \mathrm{~h}$

(ii): 2-chloro-4-methylpyrimidine, $\mathrm{Pd}\left(\mathrm{PPh}_{3}\right)_{4}, \mathrm{Na}_{2} \mathrm{CO}_{3}$, reflux, $15 \mathrm{~h}$

(iii): 4-R- $\mathrm{C}_{6} \mathrm{H}_{4}-\mathrm{CHO}$, aliquat $336, \mathrm{NaOHaq} 5 \mathrm{M}$, reflux, $3 \mathrm{~h}$

Scheme 3: Synthesis of compounds 7.

All new compounds are well soluble especially in chlorinated solvents $\left(\mathrm{DCM}, \mathrm{CHCl}_{3}\right)$ and were characterized by ${ }^{1} \mathrm{H},{ }^{13} \mathrm{C}$ NMR and HRMS spectroscopic techniques. The selectivity of the Suzuki-Miyaura cross coupling as well as condensation reactions was sufficiently high to generate all trans-isomer within the limits of NMR detection as observed previously. ${ }^{5 \mathrm{a}}$ The stereochemistry of the double bounds was unequivocally established on the basis of coupling constant for the vinylic proton in the ${ }^{1} \mathrm{H} \operatorname{NMR}(J \approx 16 \mathrm{~Hz})$. No trans/cis isomerisation were observed during photophysical experiments.

\section{X-ray Analysis}

Chromophore $\mathbf{2 h}$ provided crystals for X-ray analysis by slow evaporation of its dichloromethane/ethyl acetate (1/1, v/v) solution. The measured crystal, a large fragment of a large yellow and transparent prism, confirms the proposed molecular structure; in particular the $E$ configuration of the three vinylic linkers is confirmed (Figure 1). An orthorhombic crystal system is observed with a Pna2 ${ }_{1}$ space group. The presence of a (modelled) disorder 
on one of the two C4/C6 arm, already observed for similar structures, ${ }^{19 \mathrm{~b}}$ can be shown. Solid state supramolecular assembly of the chromophore revealed an orthorhombic crystal system with a Pna2 $2_{1}$ space group. The crystal structure shows that the angles between the planes of three benzene rings and the pyrimidine central core lower than $20^{\circ}$, indicating that they are not completely planar, in accordance with other 4-styryl- and 4,6-distyrylpyrimidines. ${ }^{9 a, 25}$ It should be noted that the dihedral angle between the phenyl ring in $\mathrm{C} 2$ position and the pyrimidine core is the lowest $\left(\sim 7^{\circ}\right)$. Bond length alternation (BLA) were calculated for the vinylic linker on each arm and were revealed to be slightly lower for the C2 arm (0.1185 $⿱$ ) $)$, than for $\mathrm{C} 4 / \mathrm{C} 6$ arms $(0.1205,0.1600$ and $0.1775 \AA$ ) indicating that the $\mathrm{C} 2$ arm imparts stronger ICT. 


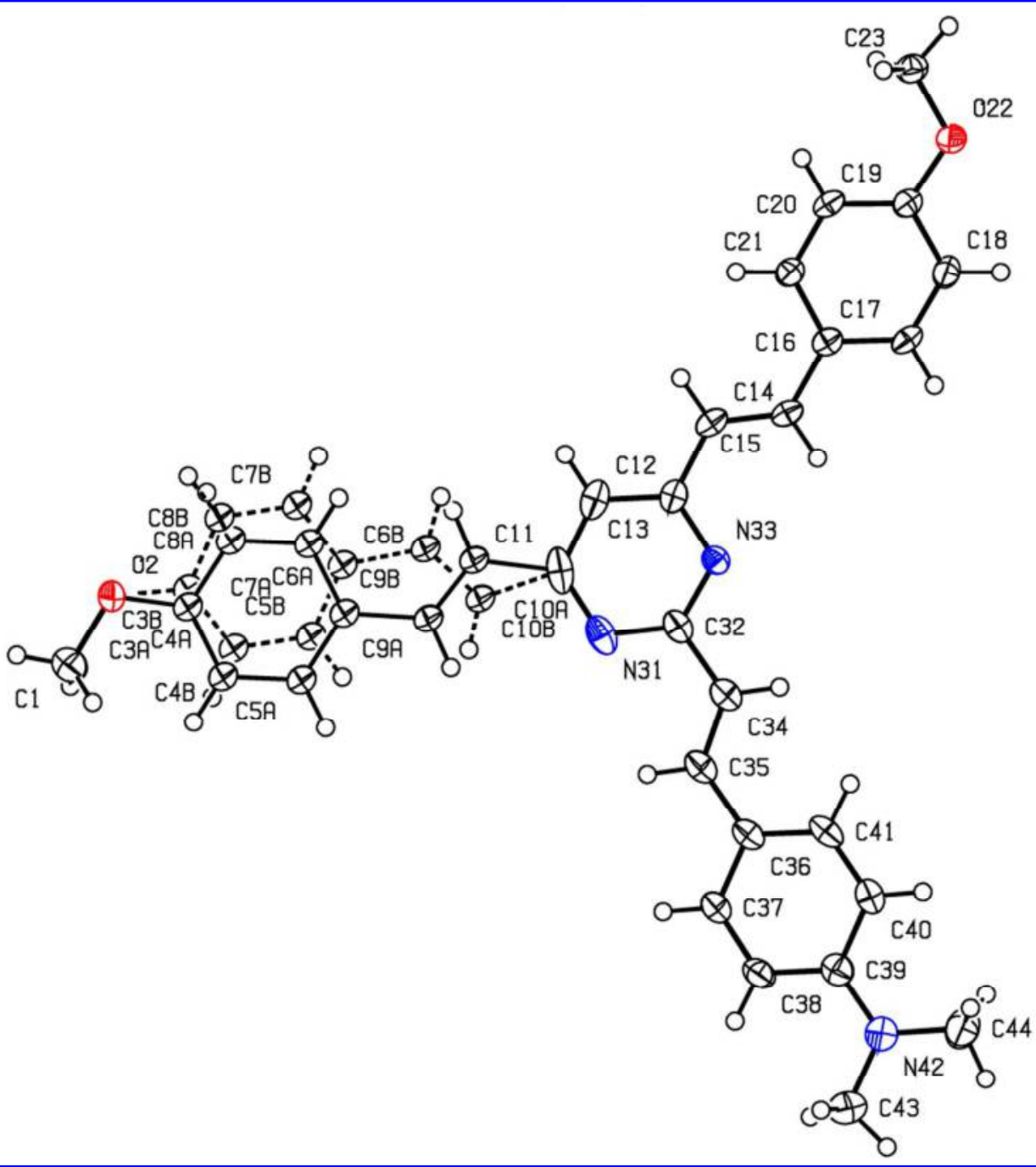

Figure 1: ORTEP drawing of the chromophore $\mathbf{2 h}$ with thermal ellipsoid at $50 \%$.

\section{Thermal properties}

Thermal behaviour of the final compounds $\mathbf{2 , 5}$ and $\mathbf{7}$ as well as compounds $\mathbf{A}_{\mathbf{2}}$ and $\mathbf{A}_{\mathbf{3}}$ was studied by differential scanning calorimetry (DSC). Figure 2 shows thermograms of representative compounds $\mathbf{2} \mathbf{i}, \mathbf{2} \mathbf{m}, \mathbf{A}_{\mathbf{2}}$ and $\mathbf{A}_{\mathbf{3}}$ while Table 1 lists all measured melting points $\left(T_{\mathrm{m}}\right)$ and temperatures of thermal decompositions $\left(T_{\mathrm{d}}\right)$. All DCS curves are given in the SI. The measured melting points range from 128 to $243{ }^{\circ} \mathrm{C}$. The temperature of decomposition was estimated within the range of $195-320^{\circ} \mathrm{C}$. Further discussion on the thermal properties is provided in the SI. 


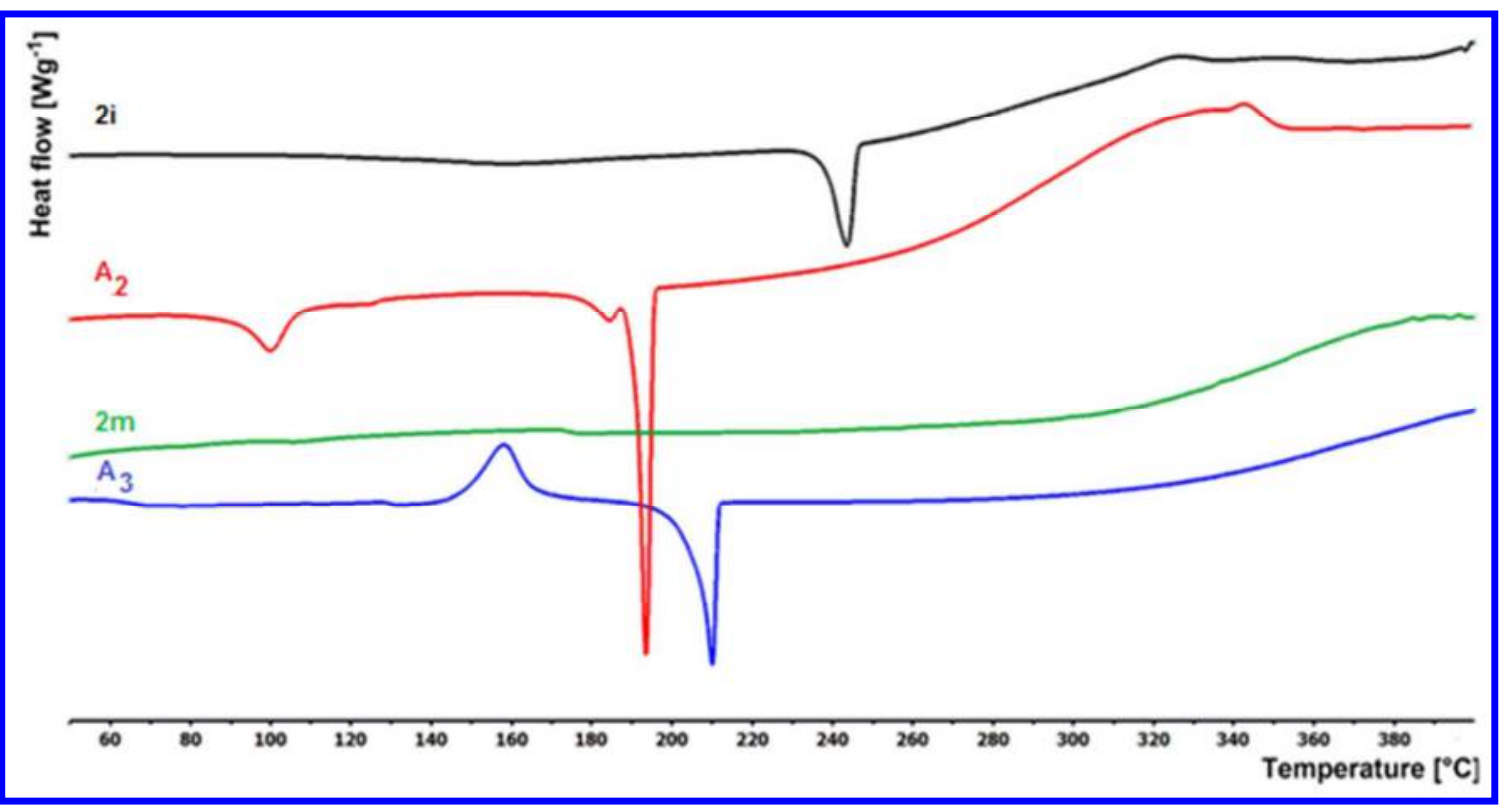

Figure 2: Representative DSC thermographs of compounds $\mathbf{2 i}, \mathbf{2 m}, \mathbf{A}_{\mathbf{2}}$ and $\mathbf{A}_{\mathbf{3}}$ obtained with a scanning rate of $3^{\circ} \mathrm{C} / \mathrm{min}$ in the range $50-400^{\circ} \mathrm{C}$

Table 1: DSC results for chromophores 2, 5, 7, $\mathbf{A}_{\mathbf{2}}$ and $\mathbf{A}_{3}$.

\begin{tabular}{ccc|ccc|ccc|ccc}
\hline Comp. & $\begin{array}{c}\boldsymbol{T}_{\mathbf{m}} \\
\left({ }^{\circ} \mathbf{C}\right)\end{array}$ & $\begin{array}{c}\boldsymbol{T}_{\mathbf{d}} \\
\left({ }^{\circ} \mathbf{C}\right)\end{array}$ & Comp. & $\begin{array}{c}\boldsymbol{T}_{\mathbf{m}} \\
\left({ }^{\circ} \mathbf{C}\right)\end{array}$ & $\begin{array}{c}\boldsymbol{T}_{\mathbf{d}} \\
\left({ }^{\circ} \mathbf{C}\right)\end{array}$ & Comp. & $\begin{array}{c}\boldsymbol{T}_{\mathbf{m}} \\
\left({ }^{\circ} \mathbf{C}\right)\end{array}$ & $\begin{array}{c}\boldsymbol{T}_{\mathbf{d}} \\
\left({ }^{\circ} \mathbf{C}\right)\end{array}$ & Comp. & $\begin{array}{c}\boldsymbol{T}_{\mathbf{m}} \\
\left({ }^{\circ} \mathbf{C}\right)\end{array}$ & $\begin{array}{c}\boldsymbol{T}_{\mathbf{d}} \\
\left({ }^{\circ} \mathbf{C}\right)\end{array}$ \\
\hline $\mathbf{2 a}$ & 193 & 300 & $\mathbf{2 h}$ & 200 & 295 & $\mathbf{2 0}$ & $/$ & 250 & $\mathbf{7 a}$ & 137 & 290 \\
$\mathbf{2 b}$ & 128 & 290 & $\mathbf{2 i}$ & $/$ & 250 & $\mathbf{2 p}$ & $/$ & 220 & $\mathbf{7 b}$ & 185 & 305 \\
$\mathbf{2 c}$ & $/$ & 245 & $\mathbf{2 j}$ & $/$ & 240 & $\mathbf{2 q}$ & $/$ & 280 & $\mathbf{7 c}$ & 243 & 265 \\
$\mathbf{2 d}$ & $/$ & 305 & $\mathbf{2 k}$ & $/$ & 310 & $\mathbf{2 r}$ & 210 & 265 & $\mathbf{7 d}$ & $/$ & 250 \\
$\mathbf{2 e}$ & 183 & 305 & $\mathbf{2 l}$ & $/$ & 195 & $\mathbf{2 s}$ & $/$ & 300 & $\mathbf{A}_{\mathbf{2}}$ & 191 & 260 \\
$\mathbf{2 f}$ & $/$ & 250 & $\mathbf{2 m}$ & $/$ & 310 & $\mathbf{5 a}$ & $/$ & 240 & $\mathbf{A}_{\mathbf{3}}$ & 205 & 320 \\
$\mathbf{2 g}$ & $/$ & 270 & $\mathbf{2 n}$ & $/$ & 290 & $\mathbf{5 b}$ & $/$ & 210 & & & \\
\hline
\end{tabular}

$T_{\mathrm{m}}=$ melting point (the point of intersection of a baseline and a tangent of thermal effect $=$ onset). $T_{\mathrm{d}}=$ thermal decomposition (pyrolysis in $\mathrm{N}_{2}$ atmosphere).

Common feature of tripodal $(\mathrm{D}-\pi)_{3}-\mathrm{A}$ or $(\mathrm{D}-\pi)_{2}-\mathrm{A}-(\pi-\mathrm{A})$ chromophores $\mathbf{2} \mathbf{a}-\mathbf{s}$ and $\mathbf{5 a}-\mathbf{b}$ is their resistance to crystallize and they often occur as solid glasses and amorphous solid. This suggests a more sophisticated thermal behaviour of centripetal star-shaped systems. Hence, their DSC curves are frequently similar and decorated by solid-solid or glass transitions. Based on the DSC analysis there are no evident general trends between type or position of particular donor used and thermal behavior of tripodal chromophores. Structural 
modifications (donor variation) often influences the thermal properties of tripodal chromophores only negligibly because the intrinsic nature of these molecules remains the same.

In general, 2,4- and 4,6-disubstituted pyrimidines (7a-d, $\quad \mathbf{A}_{2}$ and $\left.\mathbf{A}_{3}\right)$ have demonstrated a similar thermal behaviour. A presence of donor groups $\left(\mathrm{NMe}_{2}, \mathrm{OMe}\right)$ in quadrupolar molecules $7 \mathbf{b}$ and $7 \mathbf{c}$ increases the melting point up to $100{ }^{\circ} \mathrm{C}$ compared to “donor free" analogue 7a.

The $T_{\mathrm{d}}$ of tripodal molecules $\mathbf{2} \mathbf{i} / \mathbf{2} \mathbf{m}$ and their quadrupolar analogous $\mathbf{A}_{\mathbf{2}} / \mathbf{A}_{\mathbf{3}}$ are comparable (Figure 2) and dictated by the type of attached donors on the periphery. Therefore, DMA $\mathbf{2 i} / \mathbf{A}_{\mathbf{2}}$ and TPA analogous $\mathbf{2 m} / \mathbf{A}_{\mathbf{3}}$ have demonstrated almost identical $T_{\mathrm{d}}$ values $\left(250 / 260\right.$ and $310 / 320^{\circ} \mathrm{C}$, see Table 1$)$.

\section{Photophysical properties}

The UV/Vis and photoluminescence (PL) spectroscopic data of compounds 2, 5 and 7 measured in $\mathrm{CH}_{2} \mathrm{Cl}_{2}$ at room temperature are presented in Table 2. The analyses were carried out by using low concentrations of chromophores $\left(0.5-1.5 \times 10^{-5} \mathrm{M}\right)$. To facilitate comparison of photophysical properties, 4,6-distyrylpyrimidines $\mathbf{A}^{5 \mathrm{a}}$ were also included in Table 1 . As an example, the spectra of compounds $\mathbf{2 b}, \mathbf{2 c}$ and $\mathbf{2 d}$ are provided in Figure 3. 


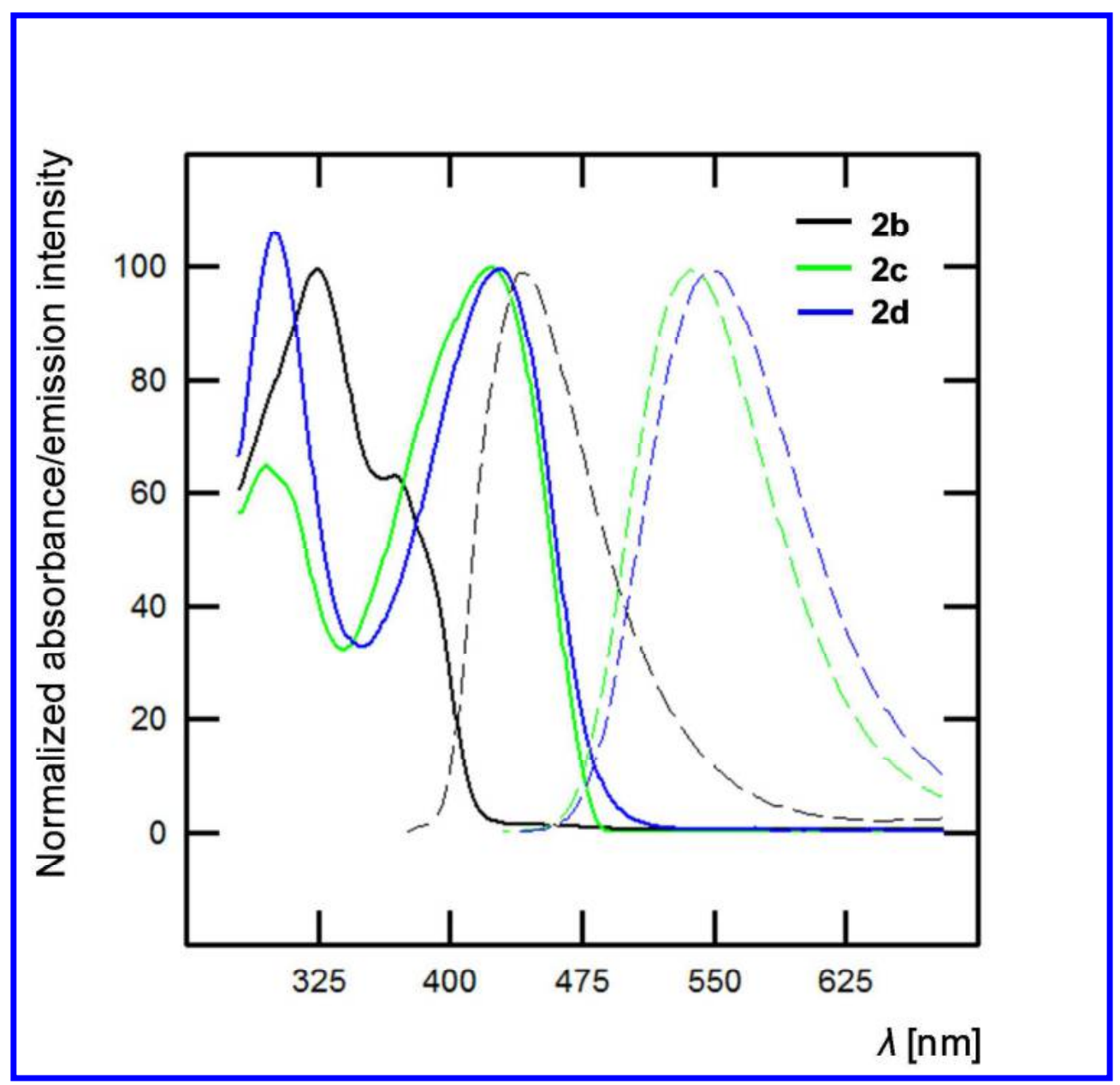

Figure 3: Normalized absorption (solid lines) and emission spectra (dashed lines) of compounds $\mathbf{2 b}$ (black), $\mathbf{2 c}$ (green) and $\mathbf{2 d}$ (green) in $\mathrm{CH}_{2} \mathrm{Cl}_{2}$ solution.

For all the compounds, the less energetic absorption band $\left(\lambda_{\max }=312-429 \mathrm{~nm}\right)$ is attributed to charge transfer. Except compounds $\mathbf{2 a}, \mathbf{2 h}, \mathbf{7 a}$ and $\mathbf{7 b}$, that are however slightly emissive in non polar heptane, all the compounds exhibit significant emission. In case of $\mathbf{2} \mathbf{h}$, the absence of emission is attributed to twisted intramolecular charge transfer excited state. For these compounds, as generally observed for pyrimidine push-pull chromophores, ${ }^{1}$ large Stokes shifts were obtained, indicating large difference (vibrational, electronic, geometric) between the Franck-Condon state and the excited state. For tristyrylpyrimidines $\mathbf{2}$ and $\mathbf{5}$, the position of absorption and emission wavelength maxima depends mainly on C4/C6 substituents. However, it should be noted that a significant red-shift in emission is observed when the $\mathrm{C} 2$ 
substituent is a significantly stronger electron-donating groups than $\mathrm{C} 4 / \mathrm{C} 6$ substituents (2j and $\mathbf{2 k}$ ). Whereas the ICT generally occurs over the C4/C6 arm, in this case, the ICT is probably prevailing on the $\mathrm{C} 2 \mathrm{arm}$. The fluorescence quantum yield varies significantly when the $\mathrm{C} 2$ substituent is modified. When tristrylpyrimidines $\mathbf{2 b - 2 d}$ with unsubstituted styryl group in $\mathrm{C} 2$ position are compared with 2,6-distyrylpyrimidines A1-A3, it appears that the addition of the styryl group in $\mathrm{C} 2$ position leads to a slight red shift of the emission maxima and a significant increase of the fluorescence quantum yield. The presence of an electrondonating group (methoxy, dimethylamino or diphenylamino) on the $\mathrm{C} 2$ arm (compounds $\mathbf{2 e -}$ $\mathbf{2 g}, \mathbf{2} \mathbf{i}, \mathbf{2}$, $2 \mathbf{2 m}$ ) results in a slight blue shift of emission regarding the corresponding unsubstituted styryl derivatives $\mathbf{2 b - 2 d}$. The opposite trend is observed for $\mathbf{2} \mathbf{j}$ and $\mathbf{2} \mathbf{k}$ probably due to change in the ICT direction over the $\mathrm{C} 2 \mathrm{arm}$. Whereas chromophores with dimethylamino group on $\mathrm{C} 4 / \mathrm{C} 6$ arms (compounds A2, 2c, 2f, 21, 2o, 2r and 5a) are generally highly luminescent, the incorporation of this fragment on $C 2$ (chromophores $\mathbf{2 h}-\mathbf{2} \mathbf{j}, \mathbf{5} \mathbf{b}$ and 7c) leads to a dramatic decrease of fluorescence quantum yield. On the other hand, the addition of a trifluoromethyl fragment, a moderately electron-withdrawing group, on $\mathrm{C} 2$ arm (chromophores $\mathbf{2 q - 2 s}$ ) results in a significant increase of the fluorescence quantum yield up to 1.00 for 2s. 2,4-Distyrylpyrimidines 7 exhibits significantly blue shifted absorption and emission with regards to their 4,6-distyryl and 2,4,6-tristyrylpyrimidines analogues. All these trends are in accordance with the observation made on arylpyrimidine series..$^{1 \mathrm{a}, 15 \mathrm{a}-\mathrm{b}}$

Table 2: UV/Vis and PL data in $\mathrm{CH}_{2} \mathrm{Cl}_{2}$.

\begin{tabular}{ccccc}
\hline & UV/vis $\lambda_{\max }, \mathrm{nm}$ & PL & & Stokes shift \\
$\mathrm{Compd}^{a}$ & $\left(\varepsilon, \mathrm{mM}^{-1} \cdot \mathrm{cm}^{-1}\right)$ & $\lambda_{\text {max }}, \mathrm{nm}$ & $\Phi_{\mathrm{F}}{ }^{\mathrm{b}}$ & $\mathrm{cm}^{-1}$ \\
\hline $\mathbf{A} 1^{17 \mathrm{a}}$ & $359(36.0)$ & 439 & - & 5076 \\
$\mathbf{A 2}^{5 \mathrm{a}}$ & $429(42.1)$ & 530 & 0.40 & 4442 \\
$\mathbf{A 3}^{5 \mathrm{a}}$ & $427(47.6)$ & 540 & 0.55 & 4901
\end{tabular}


2a

$2 b$

2c

2d

$2 e$

2f

$2 \mathrm{~g}$

2h

$2 \mathbf{i}$

$2 \mathbf{j}$

$2 \mathbf{k}$

21

$2 m$

2n

20

$2 \mathbf{p}$

$2 q$

2r

2s

$5 a$

$\mathbf{5 b}$

$7 \mathbf{a}$
$312(74.3)$

$369(35.9)$

$423(48.1)$

$430(55.0)$

$339(64.0)$

$423(45.6)$

$424(68.9)$

$370(94.0)$

$402(97.3)$

409 (112.9)

$376(61.7)$

$406(42.4)$

$415(86.2)$

$347(61.6)$

$418(52.5)$

$424(69.7)$

$370(26.8)$

$429(49.1)$

$430(60.4)$

$420(40.4)$

$386(58.1)$

$305(41.3)$
442

537

0.72

$\begin{array}{lll}551 & 0.78 & 5107\end{array}$

439

0.15

6719

$\begin{array}{lll}533 & 0.53 & 4879\end{array}$

543

0.91

5168

536

0.22

6219

577

0.03

7118

558

0.10

7799

533

0.59

5869

$\begin{array}{lll}544 & 0.56 & 5714\end{array}$

443

0.11

6245

536

0.52

5266

544

0.75

5202

$\begin{array}{lll}441 & 0.21 & 4351\end{array}$

$\begin{array}{lll}545 & 0.72 & 4961\end{array}$

$554 \quad 1.00 \quad 5205$

$\begin{array}{lll}549 & 0.68 & 5595\end{array}$

$\begin{array}{lll}548 & 0.02 & 7659\end{array}$ 


\begin{tabular}{rrrrr}
\hline $\mathbf{7 b}$ & $331(53.9)$ & - & - & - \\
$7 \mathbf{c}$ & $395(67.2)$ & 493 & 0.04 & 5032 \\
$7 \mathbf{d}$ & $402(45.5)$ & 527 & 0.72 & 5900 \\
\hline
\end{tabular}

${ }^{a}$ All spectra were recorded at room temperature at $c=0.5 \times 10^{-5} \mathrm{M}$ to $1.5 \times 10^{-5} .{ }^{b}$ Fluorescence quantum yield $( \pm 10 \%)$ determined relative to 9,10 -bisphenylethynylanthracene in cyclohexane $\left(\Phi_{\mathrm{F}}=\right.$ $1.00){ }^{26}$

In order to gain further insights into the photophysical properties of these compounds, their absorption and emission behavior was studied in a variety of aprotic solvents. While the absorption maxima were not significantly shifted, an increase in solvent polarity, estimated by Dimroth-Reichardt polarity parameter ${ }^{27}$ led to bathochromic shifts of the emission maxima. The results of emission solvatochromism are summarized in Table 3. As an example, the spectra registered for compound $\mathbf{2 g}$ are shown in Figure 4 and the change in emission color under UV irradiation for compound $\mathbf{2 k}$, easily seen by the naked eye, can be seen in Figure 5 . This solvatochromic behavior, characteristic for fluorophore featuring intramolecular charge transfer, can be explained by the stabilization of the highly polar emittting state by polar solvents. ${ }^{28}$ For all the compounds, the emission maxima were plotted versus DimrothReichardt polarity parameter (see Figures S106-S112) and, in all cases, a good linearity was observed. The emission solvatochromic behavior can be quantified by the slope of the corresponding regression line. Once again, with the exception of compound $\mathbf{2} \mathbf{k}$, the substituents in C4/C6 arm are the most affected by the emission solvatochromism with decreasing order: $\mathrm{NMe}_{2}>\mathrm{NPh}_{2}>\mathrm{OMe}$. This is in accordance to the electron-donating strength of the substituents. The slopes for 2,4-distyrylpyrimidines $\mathbf{7 c}$ and $\mathbf{7 d}$ are significantly lower than that of their 2,4,6-tristyrylpyrimidine analogues $\mathbf{2 i}$ and $\mathbf{2} \mathbf{m}$, indicating that both arms in $\mathrm{C} 4$ and $\mathrm{C} 6$ position play a role on the emission solvatochromism and, therefore on ICT into the chromophores. 
Table 3: Emission solvatochromism of pyrimidine derivatives in various aprotic solvents.

\begin{tabular}{cccccccc}
\hline & Heptane & Toluene & $\mathrm{THF}$ & $\mathrm{CH}_{2} \mathrm{Cl}_{2}$ & Acetone & $\mathrm{MeCN}$ & \multicolumn{2}{c}{$\mathrm{DMSO}$} \\
Compd & $\mathrm{E}_{\mathrm{T}}(30)^{\mathrm{a}}=30.9$ & $\mathrm{E}_{\mathrm{T}}(30)^{\mathrm{a}}=33.9$ & $\mathrm{E}_{\mathrm{T}}(30)^{\mathrm{a}}=37.4$ & $\Delta \mathrm{E}_{\mathrm{T}}(30)^{\mathrm{a}}=40.7$ & $\Delta \mathrm{E}_{\mathrm{T}}(30)^{\mathrm{a}}=42.2$ & $\Delta \mathrm{E}_{\mathrm{T}}(30)^{\mathrm{a}}=45.6$ & $\Delta \mathrm{E}_{\mathrm{T}}(30)^{\mathrm{a}}=45.1$ \\
& $\lambda_{\max }, \mathrm{nm}$ & $\lambda_{\max }, \mathrm{nm}$ & $\lambda_{\max }, \mathrm{nm}$ & $\lambda_{\max }, \mathrm{nm}$ & $\lambda_{\max }, \mathrm{nm}$ & $\lambda_{\max }, \mathrm{nm}$ & $\lambda_{\max }, \mathrm{nm}$ \\
\cline { 2 - 8 } $\mathbf{2 b}$ & 397,420 & 408,429 & 432 & 442 & 450 & 470 & 471 \\
$\mathbf{2 c}$ & 453 & 483 & 526 & 537 & 563 & 587 & 601 \\
$\mathbf{2 d}$ & 464 & 482 & 520 & 551 & 563 & 591 & 596 \\
$\mathbf{2 e}$ & 402,421 & 410,433 & 432 & 439 & 440 & 453 & 461 \\
$\mathbf{2 f}$ & 450 & 480 & 522 & 533 & 559 & 581 & 598 \\
$\mathbf{2 g}$ & 461 & 480 & 515 & 543 & 555 & 583 & 584 \\
$\mathbf{2 i}$ & 450 & 479 & 521 & 536 & 558 & 577 & 601 \\
$\mathbf{2 j}$ & 460 & 495 & 512 & 547 & 552 & 574 & 577 \\
$\mathbf{2 k}$ & 439 & 466 & 511 & 558 & 572 & 627 & 622 \\
$\mathbf{2 l}$ & 451 & 480 & 521 & 533 & 561 & 584 & 596 \\
$\mathbf{2 m}$ & 460 & 479 & 514 & 544 & 555 & 589 & 586 \\
$\mathbf{2 n}$ & 401,422 & 411,433 & 433 & 443 & 445 & 463 & 471 \\
$\mathbf{2 0}$ & 449 & 480 & 520 & 536 & 565 & 586 & 597 \\
$\mathbf{2 p}$ & 460 & 479 & 519 & 544 & 558 & 586 & 585 \\
$\mathbf{2 q}$ & 398 & 411 & 436 & 441 & 452 & 463 & 475 \\
$\mathbf{2 r}$ & 456 & 486 & 533 & 545 & 565 & 587 & 592 \\
$\mathbf{2 d}$ & 467 & 486 & 526 & 554 & 567 & 600 & 599 \\
$\mathbf{5 a}$ & 457 & 491 & 542 & 549 & 571 & 594 & 589 \\
$\mathbf{5 b}$ & 398 & 411 & 436 & 441 & 452 & 463 & 475 \\
$\mathbf{7 c}$ & 433 & 455 & 484 & 493 & 523 & 513 & 527 \\
$\mathbf{7 d}$ & 447 & 470 & 502 & 527 & 531 & 546 & 547 \\
\hline
\end{tabular}

${ }^{a}$ Dimroth-Reichardt polarity parameter, $\mathrm{kcal} \cdot \mathrm{mol}^{-1}$ 


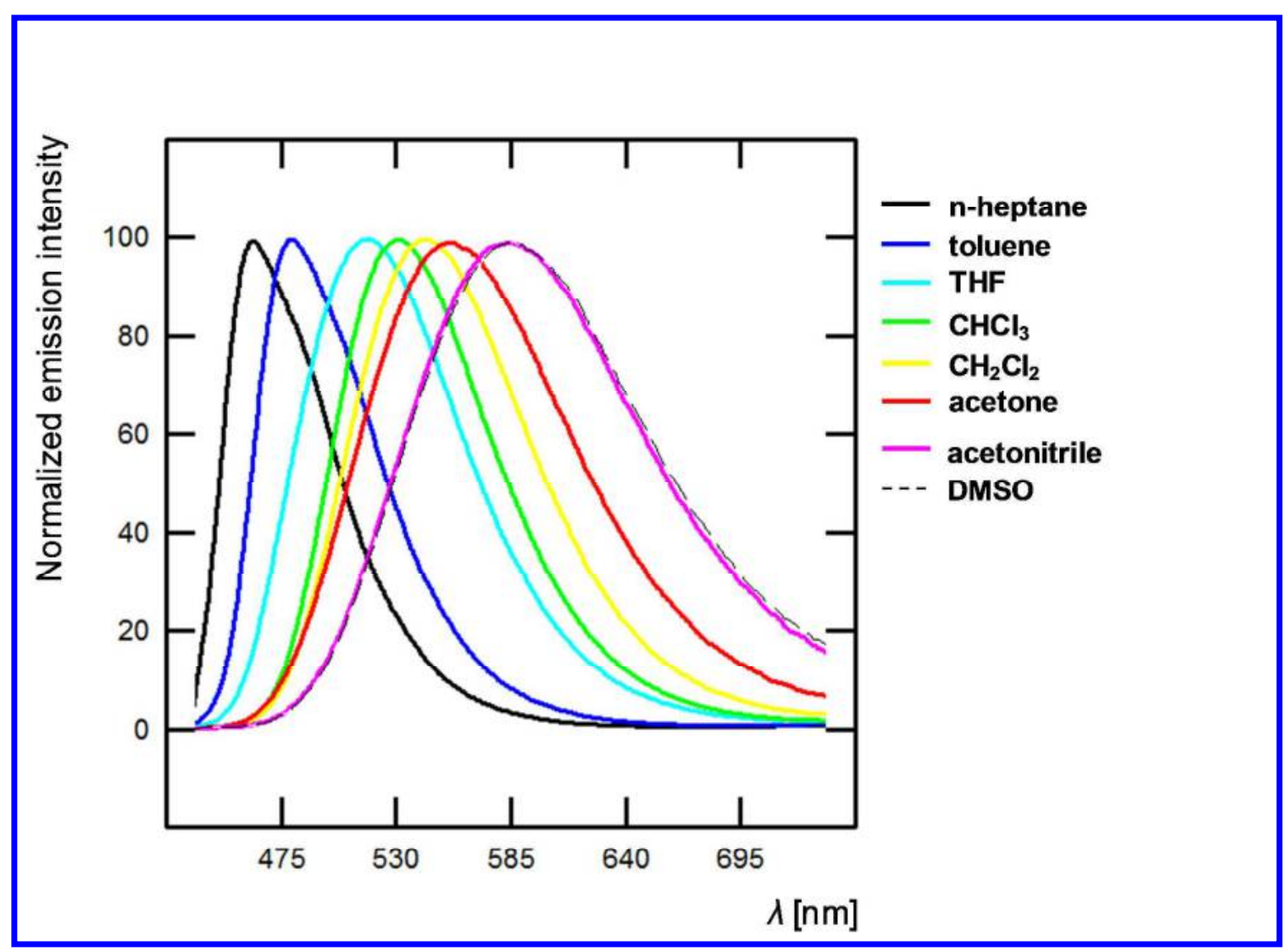

Figure 4: Normalized emission spectra of $\mathbf{2 g}$ in different aprotic solvents.

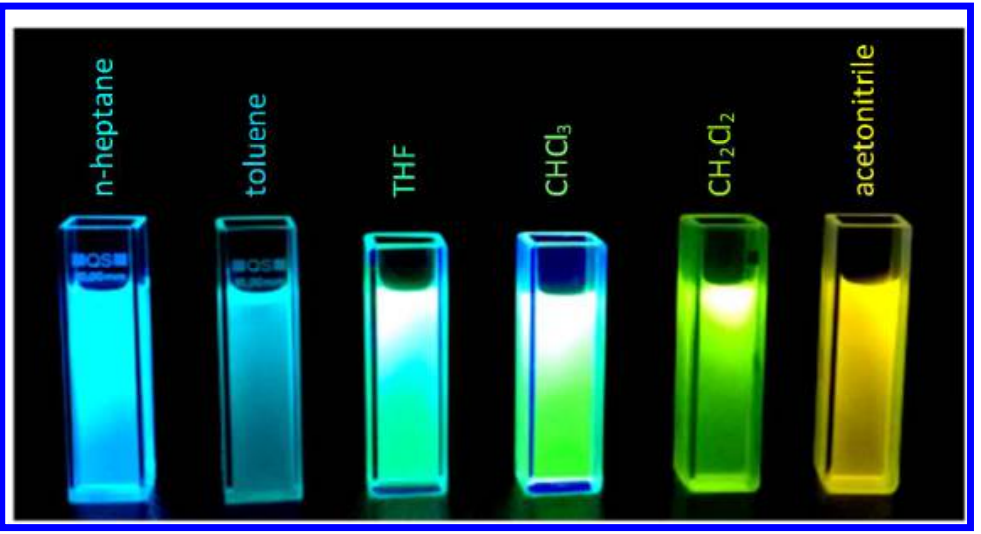

Figure 5: Fluorescence color changes experienced by $\mathbf{2 k}$ in various solvents. Picture was taken in the dark upon irradiation with a hand-held UV lamp $\left(\lambda_{\mathrm{em}}=366 \mathrm{~nm}\right)$.

The ability of protonation of pyrimidine chromophores has been already demonstrated. ${ }^{5,9}$ Generally, the protonation of amino-substituted stryrylpyrimidines results in quenching of emission; however, in the case of less electron-donating substituents, such as methoxy groups, 
the protonation lead to a red-shifted emission. ${ }^{5,9 a}$ The changes in the emission spectra of $\mathbf{2 q}$ upon addition of $(1 S)-(+)-10$-camphorsulfonic acid are illustrated in Figure 6 . The progressive disappearance of the emission band of the neutral form at $441 \mathrm{~nm}$ is observed, whereas a new red-shifted absorption band at $540 \mathrm{~nm}$ progressively appear corresponding to the monoprotonated species. ${ }^{9 a}$ As shown on Figure 7, the neutral form of $\mathbf{2 q}$ emits dark blue light under UV-irradiation whereas the protonated form emits green light. A mixture of the two forms enables to obtain cyan light.

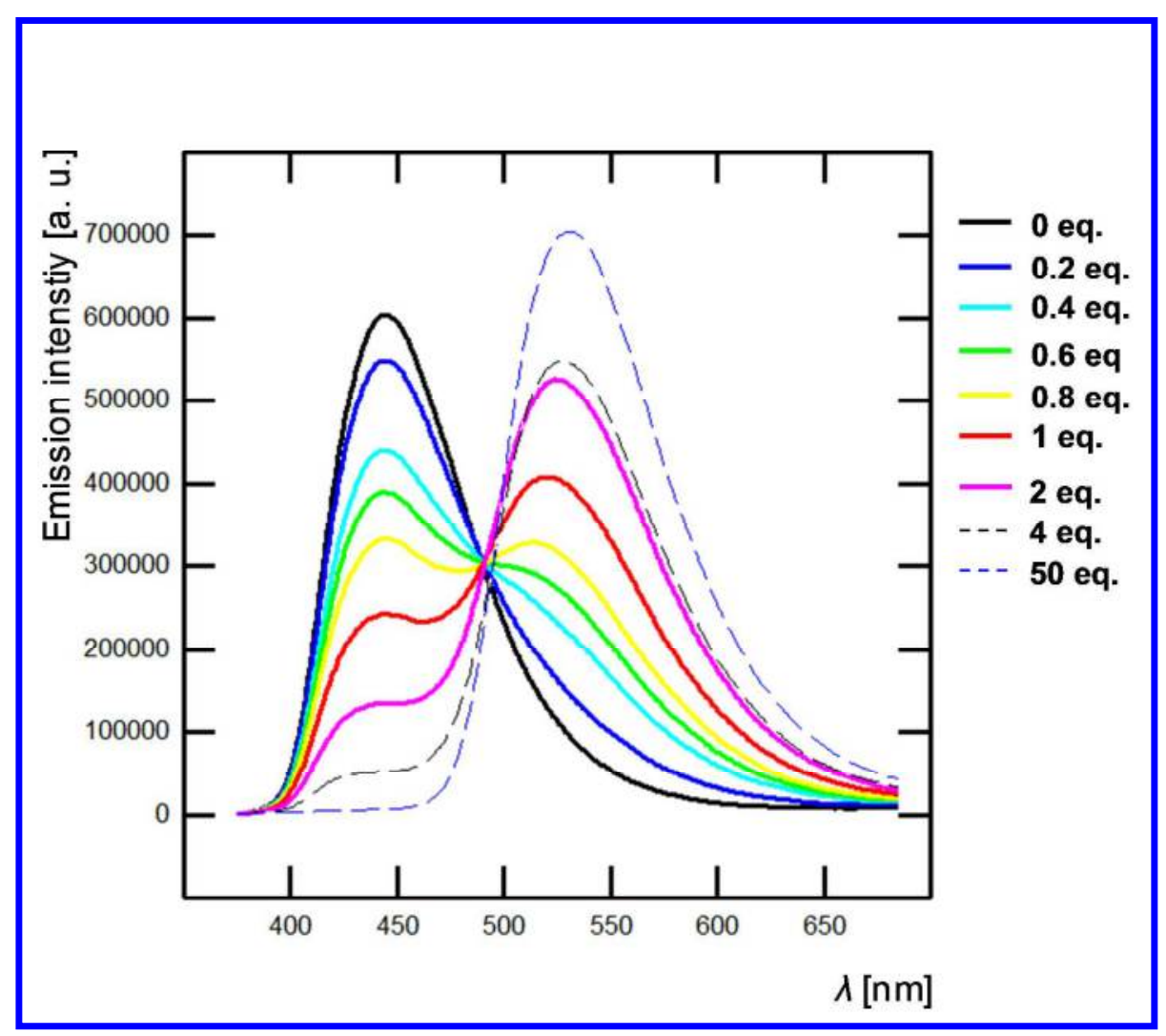

Figure 6 Changes in the emission spectra of a $\mathrm{CH}_{2} \mathrm{Cl}_{2}$ solution of $\mathbf{2 q}\left(\mathrm{c}=0.9642 \times 10^{-5} \mathrm{M}\right)$ upon addition of (1S)-(+)-10-camphorsulfonic acid $(0.1-50$ eq. $) . \lambda_{\mathrm{exc}}=380 \mathrm{~nm}$. 


\section{DFT calculations}

DFT calculations implemented in Gaussian 16 software package ${ }^{29}$ were employed to investigate the fundamental properties of representative pyrimidines $\mathbf{A 3}, \mathbf{2} \mathbf{g}, \mathbf{2} \mathbf{j}, \mathbf{2} \mathbf{k}$, and $\mathbf{2 m}$ with a systematically varied structural arrangement. Their optimized geometries, the HOMO/LUMO energies, and ground state dipole moments $\mu$ (Table 4) were obtained by DFT B3LYP/6-311+g(2d,p) method. The calculated HOMO/LUMO levels were further visualized in the energy level diagram as shown in Figure 8. Whereas the HOMO-LUMO gaps of all molecules are almost identical $(2.97-3.02 \mathrm{eV})$, the principal variations are seen at both HOMO/LUMO levels. Hence, decoration of the central pyrimidine acceptor with two or three donor arms affects the position of the HOMO and LUMO rather than the HOMO-LUMO difference. This is in accordance to our latest observation and generalization on multipodal chromophores. $^{30}$ The frontier molecular orbitals are further visualized in Figure 9. In the parent molecule A3, the HOMO is localized on both $N, N$-diphenylamino donors but is also 
mixed with the LUMO spread over the central pyrimidine and adjacent $\pi$-linkers. This implies lower charge separation. The situation is similar in $\mathbf{2 g}$ bearing weak additional 4-methoxystyryl donor appended at $\mathrm{C} 2$ (the second $N, N$-diphenylamino donor is occupied by the HOMO-1). However, by attaching strong electron releasing moieties, such as $N, N$ dimethylamino or $\mathrm{N}, \mathrm{N}$-diphenylamino groups, the HOMO has completely moved on the arms appended at $\mathrm{C} 2$ regardless what type of donors are connected at $\mathrm{C} 4 / \mathrm{C} 6$. Hence, for $\mathbf{2} \mathbf{j}, \mathbf{2} \mathbf{k}$, and $\mathbf{2 m}$, the ICT dominates from the arm connected at pyrimidine $\mathrm{C} 2$.

Table 4: DFT calculated data of representative chromophores.

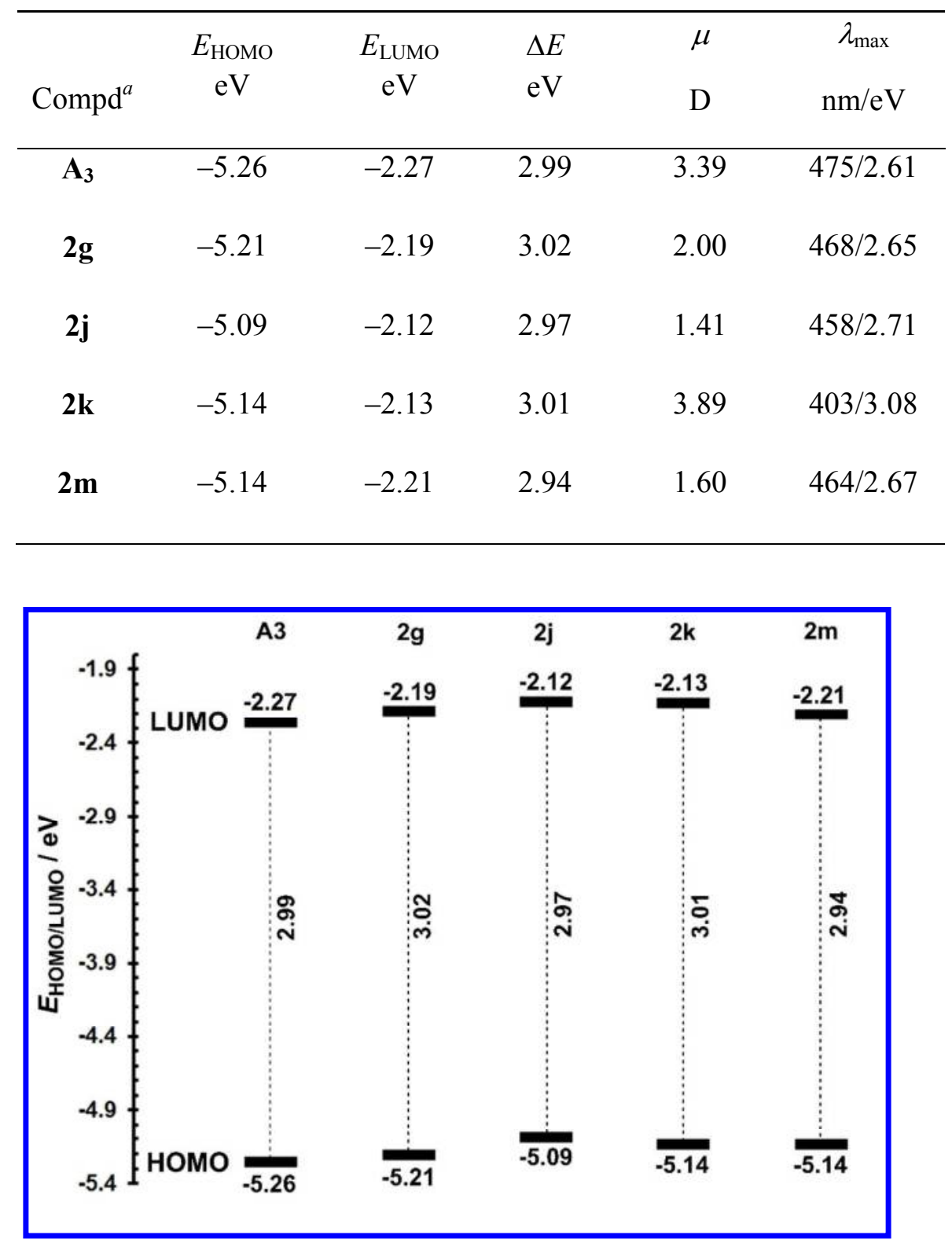


Figure 8 Energy level diagram of the DFT-derived HOMO/LUMO energies.

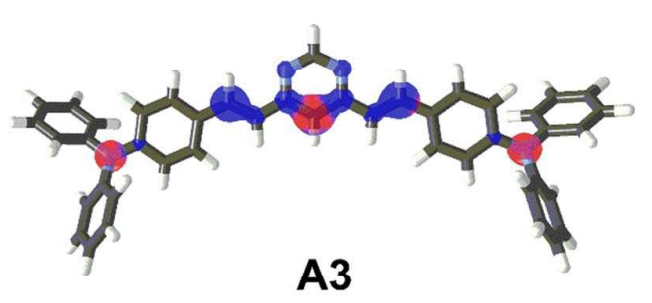

A3

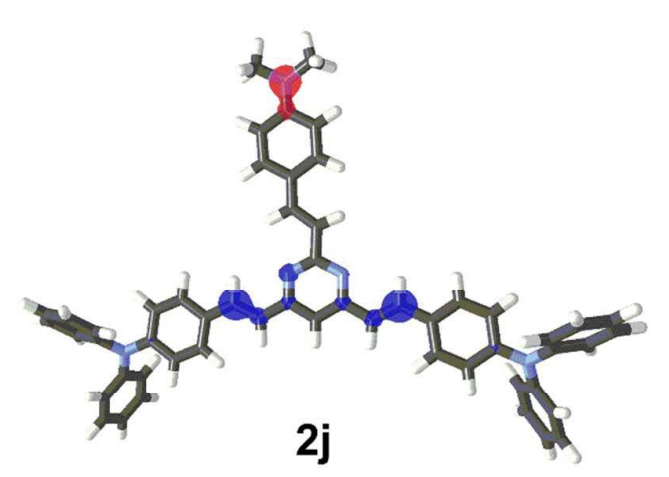

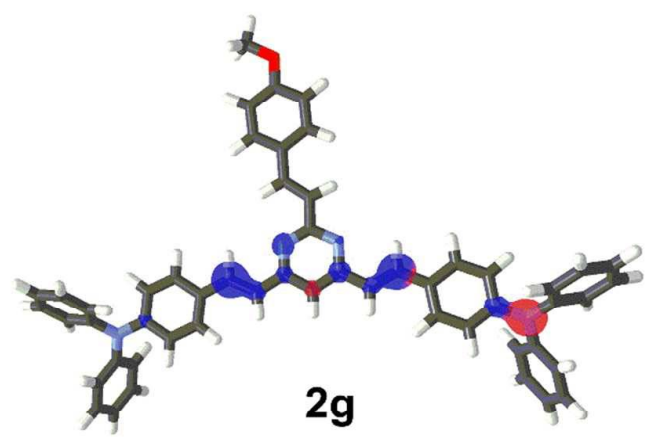

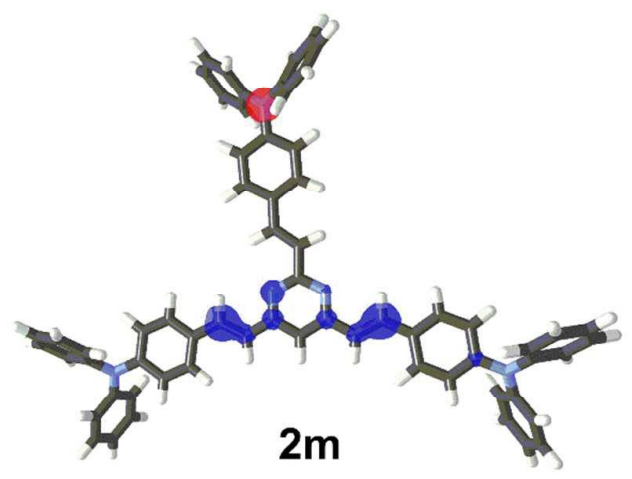

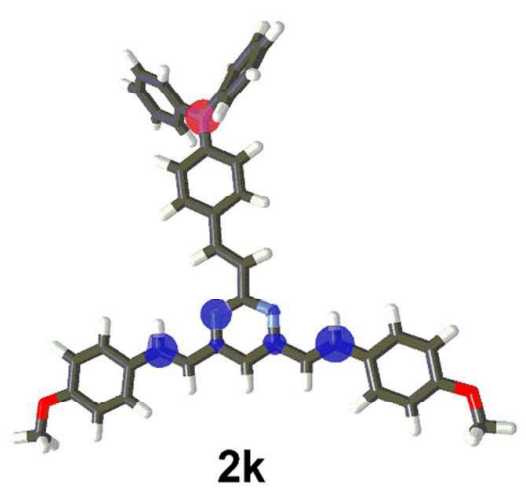

Figure 9 Optimized geometries and HOMO (red) and LUMO (blue) localizations in representative chromophores.

The electronic absorption spectra of representative chromophores were further calculated using TD-SCF (nstates $=10)$ B3LYP/6-311+g(2d,p) method. The spectra are listed in Figure S113 jointly with the experimental data; the calculated longest-wavelength absorption maxima are given in Table 3 . Their correlation with the experimental $\lambda_{\max }$ values is very tight 
as shown in Figure S114. This implies that, despite the calculated values are generally redshifted, the employed method is capable to described trends within the given series of molecules. The spectra of representative chromophores feature a low energy lying CT-band with the $\lambda_{\max }$ appearing between $403-475 \mathrm{~nm}$ (376-428 nm experimentally). Compared to tripodal molecules 2, the quadrupolar chromophore A3 showed the most bathochromically shifted CT-band $\left(\lambda_{\max }=428 \mathrm{~nm}\right)$. This may be explained by the Frenkel exciton model, which predicts splitting of the singlet excited state into two and three bands for quadrupolar and tripodal molecules, as compared to their linear analogue. Whereas for quadrupolar molecules is the low energy band dominant, the low energy lying two states of a tripodal molecule are degenerate while the third high energy state has zero oscillator strength. Hence, the absorption spectra of both types of molecules are characterized by a single CT-band, eventually accompanied by a shoulder for quadrupolar molecules and a blue-shift for tripodal ones. According to the performed calculations, the CT-bands of quadrupolar A3 and tripodal $\mathbf{2 g}$, bearing weak methoxy electron donor, are almost exclusively generated by the $\mathrm{HOMO} \rightarrow$ LUMO transition. On the other hand, the CT bands of $\mathbf{2} \mathbf{j}$ and $\mathbf{2} \mathbf{m}$, bearing all amino donors, are dominated by the HOMO $\rightarrow$ LUMO, HOMO- $1 \rightarrow$ LUMO, and HOMO $\rightarrow$ LUMO +1 transitions. Replacement of two amino donors at $\mathrm{C} 4 / \mathrm{C} 6$ as in $\mathbf{2 k}$ led to a significantly redshifted HOMO $\rightarrow$ LUMO transition ( 468 nm, see Figure S113) but with diminished oscillator strength. Hence, the observed CT-band is generated by the HOMO $\rightarrow \mathrm{LUMO}+1$ and HOMO$1 \rightarrow$ LUMO transitions.

\section{Conclusions}

In conclusion, we have successfully synthesized 2,4,6-tristyrylpyrimidine and 2,4distyrylpyrimidine chromophores with identical or different substituent on each arm. In terms of absorption and emission maxima, and calculated HOMO-LUMO gaps, 2,4,6tristyrylpyrimidines exhibits generally the similar properties as the corresponding 4,6- 
distyrylpyrimidines. Nevertheless, when the $\mathrm{C} 2$ substituent is a significantly stronger electron-donating substituents than $\mathrm{C} 4 / \mathrm{C} 6$ ones, the ICT occurs mainly on this branch and dictates the photophysical properties. In all cases, the $\mathrm{C} 2$ substituent play a key role on the emission quantum yield. As one would expected, all these materials exhibit strong emission solvatochromism and $\mathrm{pH}$ sensibility. Comparison of the two-photon absorption properties of 2,4,6-tristyrylpyrimidine with the corresponding 4,6-distyrylpyrimidines are currently under investigation.

\section{Experimental Section}

General Conditions. In air- and moisture-sensitive reactions, all glassware was flame-dried and cooled under nitrogen. Thermal behavior of the target compounds was measured in open aluminous crucibles under $\mathrm{N}_{2}$ inert atmosphere. DSC curves were determined with a scanning rate of $3{ }^{\circ} \mathrm{C} / \mathrm{min}$ within the range $25-400{ }^{\circ} \mathrm{C}$. NMR spectra were acquired at room temperature. Chemical shifts are given in parts per million relative to TMS $\left({ }^{1} \mathrm{H}, 0.0 \mathrm{ppm}\right)$ and $\mathrm{CDCl}_{3}\left({ }^{13} \mathrm{C}, 77.0 \mathrm{ppm}\right)$. Acidic impurities in $\mathrm{CDCl}_{3}$ were removed by treatment with anhydrous $\mathrm{K}_{2} \mathrm{CO}_{3}$. High resolution MALDI MS spectra were measured on a MALDI mass spectrometer equipped with nitrogen UV laser $(337 \mathrm{~nm}, 60 \mathrm{~Hz})$ and quadrupole analyser (positive-ion mode over a normal mass range $(m / z$ 50-2000) with resolution 100000 at $\mathrm{m} / \mathrm{z}=400)$. Trans-2-[3-(4-tert-butylphenyl)-2-methyl-2-propenylidene]malononitrile (DCTB) was used as a matrix. Mass spectra were averaged over the whole MS record for all measured samples. UV-vis and fluorescence spectra were recorded using standard $1 \mathrm{~cm}$ quartz cells. Compounds were excited at their absorption maxima (band of lowest energy) to record the emission spectra. The $\Phi_{\mathrm{F}}$ values were calculated using a well-known procedure with 9,10-diphenylethynylanthracene in cyclohexane as standard. ${ }^{26}$ Stokes shifts were calculated by considering the lowest energetic absorption band. All calculations were carried out in Gaussian 09W package at the DFT level of theory. The initial geometry optimizations were carried out by the PM3 method implemented in program ArgusLab and subsequently by the DFT B3LYP method using the $6-311 \mathrm{G}++(2 \mathrm{~d}, \mathrm{f}, \mathrm{p})$ basic 
set. The energies of the HOMO and LUMO ( $E_{\mathrm{HOMO}}$ and $\left.E_{\mathrm{LUMO}}\right)$, their differences $(\Delta E)$ and ground state dipole moments $(\mu)$ were calculated by the DFT B3LYP/6-311++G(2d,f,p) method.

General procedure for Suzuki-Miyaura cross-coupling reaction. The corresponding acetylene (1.57 equiv) was dissolved in THF $(20 \mathrm{~mL})$ and nitrogen was bubbled through the solution for $10 \mathrm{~min}$. Catecholborane (1.9 equiv of $1 \mathrm{M}$ solution in THF) was added and the reaction mixture was heated to reflux for $1.5 \mathrm{~h}$. The second portion of catecholborane $(0.7$ equiv) was added and heating was continued for $2 \mathrm{~h}$. The reaction mixture was cooled to room temperature and $\mathrm{Pd}\left(\mathrm{PPh}_{3}\right)_{4}(0.025$ equiv) and corresponding pyrimidine (1 equiv) were added. Solution was stirred for $20 \mathrm{~min}$ before $20 \%$ aqueous $\mathrm{Na}_{2} \mathrm{CO}_{3}(5 \mathrm{~mL})$ was added and the mixture was stirred under nitrogen at reflux for $15 \mathrm{~h}$. The reaction mixture was cooled and then diluted with $\mathrm{CH}_{2} \mathrm{Cl}_{2}(20 \mathrm{~mL})$. The organic layer was washed with water $(3 \times 20 \mathrm{~mL})$, then with brine $(20 \mathrm{~mL})$, separated, dried over $\mathrm{MgSO}_{4}$ and the solvents were evaporated under reduced pressure. The crude product was purified by column chromatography $\left(\mathrm{SiO}_{2}\right.$, indicated solvents).

General procedure for Knoevenagel condensation. Aldehyde (1 equiv) and corresponding 4-methylpyrimidine (1 equiv) or 4,6-dimethylpyrimidine ( 0.5 equiv) were added in $5 \mathrm{M}$ aqueous $\mathrm{NaOH}(15 \mathrm{~mL})$ containing Aliquat 336 (0.1 equiv). Solution was heated to reflux for $3 \mathrm{~h}$ and then cooled to room temperature. The precipitate was filtered off, washed with water, and purified by recrystallization from $\mathrm{CH}_{2} \mathrm{Cl}_{2} / n$-heptane and/or by column chromatography $\left(\mathrm{SiO}_{2}\right.$, indicated solvents).

(E)-2-Styryl-4,6-dimethylpyrimidine (1a). Synthesized from phenylacetylene (161 mg, 1.57 mmol) and 2-chloro-4,6-dimethylpyrimidine (143 $\mathrm{mg}, 1 \mathrm{mmol})$ following the general procedure for Suzuki-Miyaura reaction. The crude product was purified by column chromatography $\left(\mathrm{SiO}_{2}\right.$, petroleum ether:EtOAc, 7:3). Yield: $78 \mathrm{mg}(37 \%)$; white solid. $R_{\mathrm{f}}$ : $0.7\left(\mathrm{SiO}_{2}\right.$; petroleum ether:EtOAc, 7:3). Mp: 47.5-49.4 ${ }^{\circ} \mathrm{C}$ (lit. $\left.{ }^{31} 47-50{ }^{\circ} \mathrm{C}\right) .{ }^{1} \mathrm{H}$ NMR $(300$ 
$\left.\mathrm{MHz}, \mathrm{CDCl}_{3}\right): \delta=2.50(\mathrm{~s}, 6 \mathrm{H}), 6.86(\mathrm{~s}, 1 \mathrm{H}), 7.21\left(\mathrm{~d},{ }^{3} J=15.9 \mathrm{~Hz}, 1 \mathrm{H}\right), 7.29-7.41(\mathrm{~m}, 3 \mathrm{H})$, 7.61-7.64 (m, 2H), $7.97\left(\mathrm{~d},{ }^{3} J=15.9 \mathrm{~Hz}, 1 \mathrm{H}\right) \mathrm{ppm} .{ }^{13} \mathrm{C}$ NMR $\left(75 \mathrm{MHz}, \mathrm{CDCl}_{3}\right): \delta=24.1$, $117.7,127.7,127.9,128.8,128.9,136.4,137.6,164.3,166.6$ ppm. IR (ATR): $v=3057,1533$, 1367, 978, 747, $692 \mathrm{~cm}^{-1}$. HR-MALDI-MS (DCTB): m/z calculated for $\mathrm{C}_{14} \mathrm{H}_{15} \mathrm{~N}_{2}\left[(\mathrm{M}+\mathrm{H})^{+}\right]$ 211.1230, found 211.1227.

(E)-2-(4-Methoxystyryl)-4,6-dimethylpyrimidine (1b). Synthesized from 4-ethynylanisole (415 mg, $3.14 \mathrm{mmol}$ ) and 2-chloro-4,6-dimethylpyrimidine (286 mg, $2 \mathrm{mmol}$ ) following the general procedure for Suzuki-Miyaura reaction. The crude product was purified by column chromatography $\left(\mathrm{SiO}_{2}\right.$, petroleum ether:EtOAc, 7:3). Yield: $257 \mathrm{mg}$ (54 \%); brownish solid. $R_{\mathrm{f}}: 0.4\left(\mathrm{SiO}_{2}\right.$; petroleum ether:EtOAc, 7:3). Mp: 87.9-90.2 ${ }^{\circ} \mathrm{C} .{ }^{1} \mathrm{H}$ NMR $\left(300 \mathrm{MHz}, \mathrm{CDCl}_{3}\right)$ : $\delta=2.48(\mathrm{~s}, 6 \mathrm{H}), 3.82(\mathrm{~s}, 3 \mathrm{H}), 6.82(\mathrm{~s}, 1 \mathrm{H}), 6.89-6.92(\mathrm{~m}, 2 \mathrm{H}), 7.07\left(\mathrm{~d},{ }^{3} J=15.9 \mathrm{~Hz}, 1 \mathrm{H}\right)$, 7.54-7.57 (m, 2H), $7.92\left(\mathrm{~d},{ }^{3} J=15.9 \mathrm{~Hz}, 1 \mathrm{H}\right) \mathrm{ppm} .{ }^{13} \mathrm{C}$ NMR $\left(75 \mathrm{MHz}, \mathrm{CDCl}_{3}\right): \delta=24.1$, $55.4,114.3,117.4,125.6,129.1,129.2,137.3,160.4,164.6,166.6$ ppm. IR (ATR): $v=3004$, $1574,1511,1242,1178,1028,981,839,818,770 \mathrm{~cm}^{-1}$. HR-MALDI-MS (DCTB): m/z calculated for $\mathrm{C}_{15} \mathrm{H}_{16} \mathrm{~N}_{2} \mathrm{O}\left[\mathrm{M}^{+}\right] 240.1257$, found 240.1256 .

(E)-2-(4-Dimethylaminostyryl)-4,6-dimethylpyrimidine (1c). Synthesized from 4-ethynyl$\mathrm{N}, \mathrm{N}$-dimethylaniline $(362 \mathrm{mg}, 2.50 \mathrm{mmol})$ and 2-chloro-4,6-dimethylpyrimidine $(230 \mathrm{mg}$, $1.61 \mathrm{mmol}$ ) following the general procedure for Suzuki-Miyaura reaction. The crude product was purified by column chromatography $\left(\mathrm{SiO}_{2}\right.$, petroleum ether:EtOAc, 7:3). Yield: $244 \mathrm{mg}$ (59\%); yellow solid. $R_{\mathrm{f}}$ : $0.6\left(\mathrm{SiO}_{2}\right.$; petroleum ether:EtOAc, 7:3). Mp: $112.8-115.2{ }^{\circ} \mathrm{C} .{ }^{1} \mathrm{H}$ $\operatorname{NMR}\left(300 \mathrm{MHz}, \mathrm{CDCl}_{3}\right): \delta=2.47(\mathrm{~s}, 6 \mathrm{H}), 3.00(\mathrm{~s}, 6 \mathrm{H}), 6.69-6.72(\mathrm{~m}, 2 \mathrm{H}), 6.78(\mathrm{~s}, 1 \mathrm{H}), 7.01$ $\left(\mathrm{d},{ }^{3} J=15.9 \mathrm{~Hz}, 1 \mathrm{H}\right), 7.51-7.54(\mathrm{~m}, 2 \mathrm{H}), 7.91\left(\mathrm{~d},{ }^{3} J=15.9 \mathrm{~Hz}, 1 \mathrm{H}\right) \mathrm{ppm} .{ }^{13} \mathrm{C}$ NMR $(75 \mathrm{MHz}$, $\left.\mathrm{CDCl}_{3}\right): \delta=24.2,40.4,112.2,116.9,123.2,124.6,129.1,138.0,151.0,165.1,166.4$ ppm. IR (ATR): $v=2919,1580,1443,1356,1165,986,820,748 \mathrm{~cm}^{-1}$. HR-MALDI-MS (DCTB): m/z calculated for $\mathrm{C}_{16} \mathrm{H}_{19} \mathrm{~N}_{3}\left[\mathrm{M}^{+}\right]$253.1574, found 253.1562. 
(E)-2-(4-Diphenylaminostyryl)-4,6-dimethylpyrimidine (1d). Synthesized from 4-ethynyl$\mathrm{N}, \mathrm{N}$-diphenylaniline $(790 \mathrm{mg}, 2.94 \mathrm{mmol})$ and 2-chloro-4,6-dimethylpyrimidine $(267 \mathrm{mg}$, $1.87 \mathrm{mmol}$ ) following the general procedure for Suzuki-Miyaura reaction. The crude product was purified by column chromatography $\left(\mathrm{SiO}_{2}\right.$, petroleum ether:EtOAc, 8:2). Yield: $200 \mathrm{mg}$ (28\%); yellow solid. $R_{\mathrm{f}}$ : $0.4\left(\mathrm{SiO}_{2}\right.$; petroleum ether:EtOAc, 8:2). Mp: $132.7-135.7{ }^{\circ} \mathrm{C} .{ }^{1} \mathrm{H}$ NMR (300 MHz, $\left.\mathrm{CDCl}_{3}\right): \delta=2.49(\mathrm{~s}, 6 \mathrm{H}), 6.83(\mathrm{~s}, 1 \mathrm{H}), 7.02-7.14(\mathrm{~m}, 9 \mathrm{H}), 7.25-7.30(\mathrm{~m}$, 4H), 7.46-7.49 (m, 2H), $7.91\left(\mathrm{~d},{ }^{3} J=15.9 \mathrm{~Hz}, 1 \mathrm{H}\right) \mathrm{ppm} .{ }^{13} \mathrm{C}$ NMR $\left(75 \mathrm{MHz}, \mathrm{CDCl}_{3}\right): \delta=$ $24.1,117.3,122.6,123.5,125.1,125.6,128.6,129.4,129.9,137.3,147.4,148.6,164.6,166.5$ ppm. IR (ATR): $v=3030,1585,1488,1273,749,692 \mathrm{~cm}^{-1}$. HR-MALDI-MS (DCTB): m/z calculated for $\mathrm{C}_{26} \mathrm{H}_{23} \mathrm{~N}_{3}\left[\mathrm{M}^{+}\right]$377.1887, found 377.1888.

(E)-2-[(6-Methoxynaphtalen-2-yl)ethenyl]-4,6-dimethylpyrimidine (1e). Synthesized from 2-ethynyl-6-methoxynaphtalene $(286 \mathrm{mg}, 1.57 \mathrm{mmol})$ and 2-chloro-4,6-dimethylpyrimidine (143 mg, $1 \mathrm{mmol}$ ) following the general procedure for Suzuki-Miyaura reaction. The crude product was purified by column chromatography $\left(\mathrm{SiO}_{2}\right.$, petroleum ether:EtOAc, 7:3). Yield: $230 \mathrm{mg}$ (79 \%); yellowish solid. $R_{\mathrm{f}}: 0.3\left(\mathrm{SiO}_{2}\right.$; petroleum ether:EtOAc, 7:3). Mp: 133.5-134.9 ${ }^{\circ} \mathrm{C} .{ }^{1} \mathrm{H}$ NMR $\left(300 \mathrm{MHz}, \mathrm{CDCl}_{3}\right): \delta=2.45(\mathrm{~s}, 6 \mathrm{H}), 3.86(\mathrm{~s}, 3 \mathrm{H}), 6.75(\mathrm{~s}, 1 \mathrm{H}), 7.06-7.13(\mathrm{~m}$, 2H), $7.26\left(\mathrm{~d},{ }^{3} J=15.9 \mathrm{~Hz}, 1 \mathrm{H}\right), 7.66-7.77(\mathrm{~m}, 3 \mathrm{H}), 7.88(\mathrm{~s}, 1 \mathrm{H}), 8.09\left(\mathrm{~d},{ }^{3} J=15.9 \mathrm{~Hz}, 1 \mathrm{H}\right)$ ppm. ${ }^{13} \mathrm{C}$ NMR $\left(75 \mathrm{MHz}, \mathrm{CDCl}_{3}\right): \delta=24.0,55.3,105.9,117.4,119.1,124.4,127.0,127.3$, 128.4, 128.9, 129.9, 131.7, 134.9, 137.7, 158.2, 164.3, 166.4 ppm. IR (ATR): $v=2931,1582$, 1364, 1163, 1027, 860, 803, $665 \mathrm{~cm}^{-1}$. HR-MALDI-MS (DCTB): $\mathrm{m} / \mathrm{z}$ calculated for $\mathrm{C}_{19} \mathrm{H}_{18} \mathrm{~N}_{2} \mathrm{O}\left[\mathrm{M}^{+}\right] 290.1414$, found 290.1414.

(E)-2-(4-Trifluoromethylstyryl)-4,6-dimethylpyrimidine (1f). Synthesized from 4trifluoromethylphenylacetylene $(426 \mathrm{mg}, 2.50 \mathrm{mmol})$ and 2-chloro-4,6-dimethylpyrimidine (228 mg, $1.59 \mathrm{mmol}$ ) following the general procedure for Suzuki-Miyaura reaction. The crude product was purified by column chromatography $\left(\mathrm{SiO}_{2}\right.$, petroleum ether:EtOAc, 7:3). Yield: 
$222 \mathrm{mg}$ (50\%); yellowish solid. $R_{\mathrm{f}}$ : $0.4\left(\mathrm{SiO}_{2}\right.$; petroleum ether:EtOAc, 7:3). Mp: 94.9-96.5 ${ }^{\circ} \mathrm{C} .{ }^{1} \mathrm{H}$ NMR $\left(300 \mathrm{MHz}, \mathrm{CDCl}_{3}\right): \delta=2.50(\mathrm{~s}, 6 \mathrm{H}), 6.89(\mathrm{~s}, 1 \mathrm{H}), 7.26\left(\mathrm{~d},{ }^{3} J=15.9 \mathrm{~Hz}, 1 \mathrm{H}\right)$, 7.60-7.71 (m, 4H), $7.97\left(\mathrm{~d},{ }^{3} J=15.9 \mathrm{~Hz}, 1 \mathrm{H}\right) \mathrm{ppm} .{ }^{13} \mathrm{C}$ NMR $\left(75 \mathrm{MHz}, \mathrm{CDCl}_{3}\right): \delta=24.1$, $118.2,124.2\left(\mathrm{q},{ }^{1} J_{\mathrm{CF}}=270 \mathrm{~Hz}\right), 125.8\left(\mathrm{q},{ }^{3} J_{\mathrm{CF}}=4 \mathrm{~Hz}\right), 127.7,130.4,130.5\left(\mathrm{q},{ }^{2} J_{\mathrm{CF}}=32 \mathrm{~Hz}\right)$, 135.8, $139.9\left(\mathrm{~d},{ }^{4} J_{\mathrm{CF}}=1 \mathrm{~Hz}\right), 163.7,166.8 \mathrm{ppm} . \mathrm{IR}(\mathrm{ATR}): v=2929,1583,1319,1103,1064$, 831, $714 \mathrm{~cm}^{-1}$. HR-MALDI-MS (DCTB): $\mathrm{m} / \mathrm{z}$ calculated for $\mathrm{C}_{15} \mathrm{H}_{14} \mathrm{~F}_{3} \mathrm{~N}_{2}\left[(\mathrm{M}+\mathrm{H})^{+}\right] 279.1104$, found 279.1102 .

$(\boldsymbol{E}, \boldsymbol{E}, \boldsymbol{E})-\mathbf{2 , 4 , 6}$-Tristyrylpyrimidine (2a). Synthesized from $1 \mathrm{a}(300 \mathrm{mg}, 1.43 \mathrm{mmol})$ and benzaldehyde (303 mg, $2.85 \mathrm{mmol}$ ) following the general procedure for Knoevenagel condensation. The crude product was purified by column chromatography $\left(\mathrm{SiO}_{2}\right.$, petroleum ether:EtOAc, 9:1) and then by recrystallization from $\mathrm{CH}_{2} \mathrm{Cl}_{2} / n$-heptane. Yield: $155 \mathrm{mg}$ (28 \%); white solid. $R_{\mathrm{f}}: 0.4\left(\mathrm{SiO}_{2}\right.$; petroleum ether:EtOAc, 9:1). Mp: $193{ }^{\circ} \mathrm{C}$ (lit. $\left.{ }^{20 \mathrm{~b}} 197-199^{\circ} \mathrm{C}\right)$. ${ }^{1} \mathrm{H}$ NMR (300 MHz, $\left.\mathrm{CDCl}_{3}\right): \delta=7.08-7.16(\mathrm{~m}, 3 \mathrm{H}), 7.28-7.43(\mathrm{~m}, 10 \mathrm{H}), 7.62-7.69(\mathrm{~m}, 6 \mathrm{H})$, $7.93\left(\mathrm{~d},{ }^{3} J=15.9 \mathrm{~Hz}, 2 \mathrm{H}\right), 8.11\left(\mathrm{~d},{ }^{3} J=15.9 \mathrm{~Hz}, 1 \mathrm{H}\right) \mathrm{ppm} .{ }^{13} \mathrm{C}$ NMR $\left(75 \mathrm{MHz}, \mathrm{CDCl}_{3}\right): \delta=$ $113.7,126.5,127.7,127.8,128.3,128.8,128.9,129.3,136.0,136.4,136.7,137.9,162.9$, $164.6 \mathrm{ppm}$ All the atoms of carbon were not observed. IR (ATR): $v=3025,1635,1564$, 1514, 1368, 963, 739, $689 \mathrm{~cm}^{-1}$. HR-MALDI-MS (DCTB): m/z calculated for $\mathrm{C}_{28} \mathrm{H}_{23} \mathrm{~N}_{2}$ $\left[(\mathrm{M}+\mathrm{H})^{+}\right] 387.1856$, found 387.1855 .

(E,E,E)-2-Styryl-4,6-bis(4-methoxystyryl)pyrimidine (2b). Synthesized from 1a (78 mg, $0.37 \mathrm{mmol})$ and 4-methoxybenzaldehyde (102 $\mathrm{mg}, 0.74 \mathrm{mmol})$ following the general procedure for Knoevenagel condensation. The crude product was purified by column chromatography $\left(\mathrm{SiO}_{2}\right.$, petroleum ether:EtOAc, 8:2) and then by recrystallization from $\mathrm{CH}_{2} \mathrm{Cl}_{2} / n$-heptane. Yield: $40 \mathrm{mg}(24 \%)$; yellowish solid. $R_{\mathrm{f}}: 0.4 \quad\left(\mathrm{SiO}_{2}\right.$; petroleum ether:EtOAc, 8:2). Mp: $128{ }^{\circ} \mathrm{C} .{ }^{1} \mathrm{H}$ NMR $\left(300 \mathrm{MHz}, \mathrm{CDCl}_{3}\right): \delta=3.86(\mathrm{~s}, 6 \mathrm{H}), 6.93-7.01$ (m, $6 \mathrm{H}), 7.11(\mathrm{~s}, 1 \mathrm{H}), 7.29-7.44(\mathrm{~m}, 4 \mathrm{H}), 7.58-7.61(\mathrm{~m}, 4 \mathrm{H}), 7.68-7.70(\mathrm{~m}, 2 \mathrm{H}), 7.89\left(\mathrm{~d},{ }^{3} J=\right.$ 
$15.9 \mathrm{~Hz}, 2 \mathrm{H}), 8.11\left(\mathrm{~d},{ }^{3} J=15.9 \mathrm{~Hz}, 1 \mathrm{H}\right) \mathrm{ppm} .{ }^{13} \mathrm{C} \mathrm{NMR}\left(75 \mathrm{MHz}, \mathrm{CDCl}_{3}\right): \delta=55.5,113.2$, $114.5,124.4,127.8,128.5,128.9,128.90,128.91,129.2,136.2,136.6,137.6,160.7,163.1$, 164.5 ppm. IR (ATR): $v=2837,1604,1560,1501,1251,1171,1152,967,749 \mathrm{~cm}^{-1} . \mathrm{HR}-$ MALDI-MS (DCTB): m/z calculated for $\mathrm{C}_{30} \mathrm{H}_{27} \mathrm{~N}_{2} \mathrm{O}_{2}\left[(\mathrm{M}+\mathrm{H})^{+}\right]$447.2067, found 447.2064. (E,E,E)-2-Styryl-4,6-bis(4-dimethylaminostyryl)pyrimidine (2c). Synthesized from 1a (150 mg, $0.71 \mathrm{mmol})$ and 4- $N, N$-dimethylaminobenzaldehyde (213 mg, $1.43 \mathrm{mmol})$ following the general procedure for Knoevenagel condensation. The crude product was purified by column chromatography ( $\mathrm{SiO}_{2}$, petroleum ether:EtOAc, 8:2) and then by recrystallization from $\mathrm{CH}_{2} \mathrm{Cl}_{2} / n$-heptane. Yield: $63 \mathrm{mg}(17 \%)$; black solid. $R_{\mathrm{f}}$ : $0.2\left(\mathrm{SiO}_{2} ;\right.$ petroleum ether:EtOAc, 8:2). $T_{\mathrm{d}}: 245{ }^{\circ} \mathrm{C} .{ }^{1} \mathrm{H}$ NMR $\left(300 \mathrm{MHz}, \mathrm{CDCl}_{3}\right): \delta=3.03(\mathrm{~s}, 12 \mathrm{H}), 6.71-6.74(\mathrm{~m}$, 4H), $6.91\left(\mathrm{~d},{ }^{3} \mathrm{~J}=15.9 \mathrm{~Hz}, 2 \mathrm{H}\right), 7.08(\mathrm{~s}, 1 \mathrm{H}), 7.28-7.35(\mathrm{~m}, 4 \mathrm{H}), 7.53-7.56(\mathrm{~m}, 4 \mathrm{H}), 7.68-$ $7.70(\mathrm{~m}, 2 \mathrm{H}), 7.86\left(\mathrm{~d},{ }^{3} J=15.9 \mathrm{~Hz}, 2 \mathrm{H}\right), 8.10\left(\mathrm{~d},{ }^{3} \mathrm{~J}=15.9 \mathrm{~Hz}, 1 \mathrm{H}\right) \mathrm{ppm} .{ }^{13} \mathrm{C}$ NMR $(75 \mathrm{MHz}$, $\left.\mathrm{CDCl}_{3}\right): \delta=40.4,112.2,112.4,114.2,114.7,121.9,124.3,127.8,128.7,128.8,129.2,136.8$, 137.2, 151.2, 163.4, 164.3 ppm. IR (ATR): $v=2892,1602,1555,1503,1363,1162,965$, 800, $746 \mathrm{~cm}^{-1}$. HR-MALDI-MS (DCTB): $\mathrm{m} / \mathrm{z}$ calculated for $\mathrm{C}_{32} \mathrm{H}_{32} \mathrm{~N}_{4}\left[\mathrm{M}^{+}\right]$472.2622, found 472.2620.

(E,E,E)-2-Styryl-4,6-bis(4-diphenylaminostyryl)pyrimidine (2d). Synthesized from 1a (300 mg, $1.43 \mathrm{mmol})$ and 4- $N, N$-diphenylaminobenzaldehyde (780 mg, $2.85 \mathrm{mmol}$ ) following the general procedure for Knoevenagel condensation. The crude product was purified by column chromatography $\left(\mathrm{SiO}_{2}\right.$, petroleum ether:EtOAc, 9:1) and then by recrystallization from $\mathrm{CH}_{2} \mathrm{Cl}_{2} / n$-heptane. Yield: $220 \mathrm{mg}(21 \%)$; yellow solid. $R_{\mathrm{f}}$ : $0.4\left(\mathrm{SiO}_{2}\right.$; petroleum ether:EtOAc, 9:1). $T_{\mathrm{d}}: 305{ }^{\circ} \mathrm{C} .{ }^{1} \mathrm{H}$ NMR $\left(300 \mathrm{MHz}, \mathrm{CDCl}_{3}\right): \delta=6.98\left(\mathrm{~d},{ }^{3} \mathrm{~J}=15.9 \mathrm{~Hz}, 2 \mathrm{H}\right)$, 7.05-7.17 (m, 17H), 7.27-7.43 (m, 12H), 7.48-7.51 (m, 4H), 7.67-7.70 (m, 2H), $7.87\left(\mathrm{~d},{ }^{3} J=\right.$ $15.9 \mathrm{~Hz}, 2 \mathrm{H}), 8.10\left(\mathrm{~d},{ }^{3} \mathrm{~J}=15.9 \mathrm{~Hz}, 1 \mathrm{H}\right) \mathrm{ppm} .{ }^{13} \mathrm{C} \mathrm{NMR}\left(75 \mathrm{MHz}, \mathrm{CDCl}_{3}\right): \delta=113.1,122.5$, $123.8,124.4,125.2,127.8,128.6,128.77,128.85,128.88,129.56,129.59,136.1,136.6$, 
137.6, 147.3, 149.0, 163.1, 164.6 ppm. IR (ATR): $v=3033,1559,1490,1274,969,748,693$ $\mathrm{cm}^{-1}$. HR-MALDI-MS (DCTB): $\mathrm{m} / \mathrm{z}$ calculated for $\mathrm{C}_{52} \mathrm{H}_{40} \mathrm{~N}_{4}\left[\mathrm{M}^{+}\right] 720.3248$, found 720.3252 .

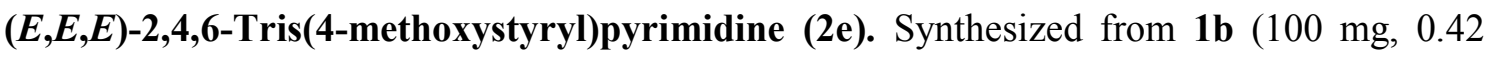
mmol) and 4-methoxybenzaldehyde $(114 \mathrm{mg}, 0.83 \mathrm{mmol})$ following the general procedure for Knoevenagel condensation. The crude product was purified by recrystallization from $\mathrm{CH}_{2} \mathrm{Cl}_{2} / n$-heptane. Yield: $156 \mathrm{mg}(79 \%)$; yellowish solid. $R_{\mathrm{f}}: 0.4 \quad\left(\mathrm{SiO}_{2} ;\right.$ petroleum ether:EtOAc, 8:2). Mp: $183{ }^{\circ} \mathrm{C} .{ }^{1} \mathrm{H}$ NMR (300 MHz, $\left.\mathrm{CDCl}_{3}\right): \delta=3.85$ (s, 9H), 6.93-7.00 (m, 8H), $7.08(\mathrm{~s}, 1 \mathrm{H}), 7.18\left(\mathrm{~d},{ }^{3} J=15.9 \mathrm{~Hz}, 1 \mathrm{H}\right), 7.57-7.65(\mathrm{~m}, 6 \mathrm{H}), 7.88\left(\mathrm{~d},{ }^{3} J=15.9 \mathrm{~Hz}, 2 \mathrm{H}\right)$, $8.06\left(\mathrm{~d},{ }^{3} J=15.9 \mathrm{~Hz}, 1 \mathrm{H}\right) \mathrm{ppm} .{ }^{13} \mathrm{C} \mathrm{NMR}\left(75 \mathrm{MHz}, \mathrm{CDCl}_{3}\right): \delta=55.46,55.49,112.8,114.34$, $114.4,124.5,126.3,129.0,129.2,129.4,136.1,137.3,160.4,160.7,163.1,164.8$ ppm All the atoms of carbon were not observed.. IR (ATR): $v=2933,1602,1559,1506,1245,1169$, 1028, 959, 868, 810, $767 \mathrm{~cm}^{-1}$. HR-MALDI-MS (DCTB): $\mathrm{m} / \mathrm{z}$ calculated for $\mathrm{C}_{31} \mathrm{H}_{28} \mathrm{~N}_{2} \mathrm{O}_{3}$ $\left[\mathrm{M}^{+}\right]$476.2094, found 476.2094.

(E,E,E)-2-(4-Methoxystyryl)-4,6-bis(4-dimethylaminostyryl)pyrimidine (2f). Synthesized from $1 \mathbf{b}(100 \mathrm{mg}, 0.42 \mathrm{mmol})$ and 4- $N, N$-dimethylaminobenzaldehyde (125 mg, $0.83 \mathrm{mmol})$ following the general procedure for Knoevenagel condensation. The crude product was purified by recrystallization from $\mathrm{CH}_{2} \mathrm{Cl}_{2} / n$-heptane. Yield: $154 \mathrm{mg}(74 \%)$; red solid. $R_{\mathrm{f}}: 0.3$ $\left(\mathrm{SiO}_{2}\right.$; petroleum ether:EtOAc, 8:2). $T_{\mathrm{d}}: 250{ }^{\circ} \mathrm{C} .{ }^{1} \mathrm{H}$ NMR $\left(300 \mathrm{MHz}, \mathrm{CDCl}_{3}\right): \delta=3.03(\mathrm{~s}$, 12H), $3.85(\mathrm{~s}, 3 \mathrm{H}), 6.71-6.74(\mathrm{~m}, 4 \mathrm{H}), 6.88-6.95(\mathrm{~m}, 4 \mathrm{H}), 7.07(\mathrm{~s}, 1 \mathrm{H}), 7.17\left(\mathrm{~d},{ }^{3} J=15.9 \mathrm{~Hz}\right.$, 1H), 7.52-7.55 (m, 4H), 7.62-7.65 (m, 2H), $7.84\left(\mathrm{~d},{ }^{3} J=15.9 \mathrm{~Hz}, 2 \mathrm{H}\right), 8.05\left(\mathrm{~d},{ }^{3} J=15.9 \mathrm{~Hz}\right.$, 1H) ppm. ${ }^{13} \mathrm{C}$ NMR $\left(75 \mathrm{MHz}, \mathrm{CDCl}_{3}\right): \delta=40.4,55.4,112.1,112.2,114.3,122.0,124.3$, $126.6,129.1,129.6,136.6,136.8,151.1,160.2,163.3,164.7 \mathrm{ppm}$ All the atoms of carbon were not observed.. IR (ATR): $v=2924,1600,1550,1497,1355,1244,1142,971,806 \mathrm{~cm}^{-1}$. HR-MALDI-MS (DCTB): m/z calculated for $\mathrm{C}_{33} \mathrm{H}_{34} \mathrm{~N}_{4} \mathrm{O}\left[\mathrm{M}^{+}\right]$502.2727, found 502.2731. 
(E,E,E)-2-(4-Methoxystyryl)-4,6-bis(4-diphenylaminostyryl)pyrimidine (2g). Synthesized from $1 \mathbf{b}(100 \mathrm{mg}, 0.42 \mathrm{mmol})$ and 4- $N, N$-diphenylaminobenzaldehyde (228 $\mathrm{mg}, 0.83 \mathrm{mmol})$ following the general procedure for Knoevenagel condensation. The crude product was purified by recrystallization from $\mathrm{CH}_{2} \mathrm{Cl}_{2} / n$-heptane. Yield: $225 \mathrm{mg}(72 \%)$; yellow solid. $R_{\mathrm{f}}$ : $0.7\left(\mathrm{SiO}_{2}\right.$; petroleum ether:EtOAc, 8:2). $T_{\mathrm{d}}: 270{ }^{\circ} \mathrm{C} .{ }^{1} \mathrm{H}$ NMR $\left(300 \mathrm{MHz}, \mathrm{CDCl}_{3}\right): \delta=3.85(\mathrm{~s}$, 3H), 6.92-7.21 (m, 24H), 7.27-7.32 (m, 6H), 7.48-7.50 (m, 4H), 7.61-7.64 (m, 2H), $7.86(\mathrm{~d}$, $\left.{ }^{3} J=15.9 \mathrm{~Hz}, 2 \mathrm{H}\right), 8.06\left(\mathrm{~d},{ }^{3} J=15.9 \mathrm{~Hz}, 1 \mathrm{H}\right) \mathrm{ppm} .{ }^{13} \mathrm{C} \mathrm{NMR}\left(75 \mathrm{MHz}, \mathrm{CDCl}_{3}\right): \delta=55.5$, $112.8,114.3,122.6,123.7,124.5,125.2,126.3,128.7,129.2,129.4,129.5,129.7,136.0$, 137.2, 147.4, 149.0, 160.4, 163.0, 164.9 ppm. IR (ATR): $v=3033,1562,1489,1271,1242$, 1168, 972, 818, 749, $691 \mathrm{~cm}^{-1}$. HR-MALDI-MS (DCTB): m/z calculated for $\mathrm{C}_{53} \mathrm{H}_{42} \mathrm{~N}_{4} \mathrm{O}\left[\mathrm{M}^{+}\right]$ 750.3353 , found 750.3361 .

(E,E,E)-2-(4-Dimethylaminostyryl)-4,6-bis(4-methoxystyryl)pyrimidine (2h). Synthesized from 1c (110 mg, $0.43 \mathrm{mmol})$ and 4-methoxybenzaldehyde (119 mg, $0.87 \mathrm{mmol})$ following the general procedure for Knoevenagel condensation. The crude product was purified by recrystallization from $\mathrm{CH}_{2} \mathrm{Cl}_{2} / n$-heptane. Yield: $121 \mathrm{mg}(57 \%)$; brown solid. $R_{\mathrm{f}}: 0.3\left(\mathrm{SiO}_{2}\right.$; petroleum ether:EtOAc, 8:2). Mp: $200{ }^{\circ} \mathrm{C} .{ }^{1} \mathrm{H}$ NMR (300 MHz, $\left.\mathrm{CDCl}_{3}\right): \delta=3.02(\mathrm{~s}, 6 \mathrm{H}), 3.85$ (s, 6H), 6.72-6.75 (m, 2H), 6.93-7.00 (m, 6H), $7.05(\mathrm{~s}, 1 \mathrm{H}), 7.12\left(\mathrm{~d},{ }^{3} J=15.9 \mathrm{~Hz}, 1 \mathrm{H}\right), 7.57-$ $7.61(\mathrm{~m}, 6 \mathrm{H}), 7.87\left(\mathrm{~d},{ }^{3} J=15.9 \mathrm{~Hz}, 2 \mathrm{H}\right), 8.05\left(\mathrm{~d},{ }^{3} \mathrm{~J}=15.9 \mathrm{~Hz}, 1 \mathrm{H}\right) \mathrm{ppm} .{ }^{13} \mathrm{C}$ NMR $(75 \mathrm{MHz}$, $\left.\mathrm{CDCl}_{3}\right): \delta=40.4,55.5,112.2,112.4,114.4,123.7,124.7,124.8,129.0,129.2,135.9,138.1$, 151.0, 160.6, 163.0, $165.4 \mathrm{ppm}$ All the atoms of carbon were not observed. IR (ATR): $v=$ 2924, 1603, 1558, 1502, 1357, 1249, 1168, 1028, 961, $810 \mathrm{~cm}^{-1}$. HR-MALDI-MS (DCTB): $\mathrm{m} / \mathrm{z}$ calculated for $\mathrm{C}_{32} \mathrm{H}_{31} \mathrm{~N}_{3} \mathrm{O}_{2}\left[\mathrm{M}^{+}\right]$489.2411, found 489.2414.

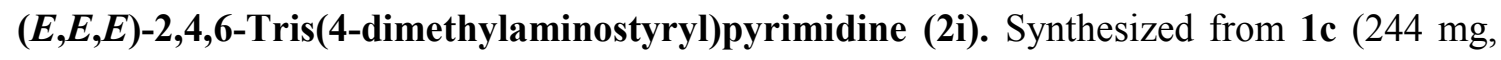
$0.96 \mathrm{mmol})$ and 4-N,N-dimethylaminobenzaldehyde (287 $\mathrm{mg}, 1.92 \mathrm{mmol})$ following the 
general procedure for Knoevenagel condensation. The crude product was purified by recrystallization from $\mathrm{CH}_{2} \mathrm{Cl}_{2} / n$-heptane. Yield: $212 \mathrm{mg}$ (43\%); brown solid. $R_{\mathrm{f}}$ : $0.1\left(\mathrm{SiO}_{2}\right.$; petroleum ether:EtOAc, 8:2). $T_{\mathrm{d}}: 250{ }^{\circ} \mathrm{C} .{ }^{1} \mathrm{H}$ NMR $\left(300 \mathrm{MHz}, \mathrm{CDCl}_{3}\right): \delta=3.02-3.03(\mathrm{~m}$, $18 \mathrm{H}), 6.71-6.75(\mathrm{~m}, 6 \mathrm{H}), 6.91\left(\mathrm{~d},{ }^{3} J=15.9 \mathrm{~Hz}, 2 \mathrm{H}\right), 7.05(\mathrm{~s}, 1 \mathrm{H}), 7.11\left(\mathrm{~d},{ }^{3} J=15.6 \mathrm{~Hz}, 1 \mathrm{H}\right)$, 7.53-7.61 (m, 6H), $7.83\left(\mathrm{~d},{ }^{3} J=15.9 \mathrm{~Hz}, 2 \mathrm{H}\right), 8.03\left(\mathrm{~d},{ }^{3} J=15.9 \mathrm{~Hz}, 1 \mathrm{H}\right) \mathrm{ppm} .{ }^{13} \mathrm{C}$ NMR $(75$ $\left.\mathrm{MHz}, \mathrm{CDCl}_{3}\right): \delta=40.4,40.5,111.6,112.3,122.3,124.2,124.4,125.0,129.1,136.4,137.6$, $150.9,151.1,163.2,165.2 \mathrm{ppm}$ All the atoms of carbon were not observed. IR (ATR): $v=$ 2888, 1599, 1502, 1356, 1167, 965, $797 \mathrm{~cm}^{-1}$. HR-MALDI-MS (DCTB): m/z calculated for $\mathrm{C}_{34} \mathrm{H}_{37} \mathrm{~N}_{5}\left[\mathrm{M}^{+}\right]$515.3044, found 515.3044.

(E,E,E)-2-(4-Dimethylaminostyryl)-4,6-bis(4-diphenylaminostyryl)pyrimidine

$(2 \mathbf{j})$.

Synthesized from 1c (110 mg, $0.43 \mathrm{mmol})$ and 4- $N, N$-diphenylaminobenzaldehyde $(238 \mathrm{mg}$, $0.87 \mathrm{mmol}$ ) following the general procedure for Knoevenagel condensation. The crude product was purified by recrystallization from $\mathrm{CH}_{2} \mathrm{Cl}_{2} / n$-heptane. Yield: $225 \mathrm{mg}$ (68 \%); yellow solid. $R_{\mathrm{f}}$ : $0.6\left(\mathrm{SiO}_{2}\right.$; petroleum ether:EtOAc, 8:2). $T_{\mathrm{d}}: 240{ }^{\circ} \mathrm{C} .{ }^{1} \mathrm{H}$ NMR $(300 \mathrm{MHz}$, $\left.\mathrm{CDCl}_{3}\right): \delta=3.02(\mathrm{~s}, 6 \mathrm{H}), 6.72-6.75(\mathrm{~m}, 2 \mathrm{H}), 6.99\left(\mathrm{~d},{ }^{3} J=15.9 \mathrm{~Hz}, 2 \mathrm{H}\right), 7.05-7.16(\mathrm{~m}, 18 \mathrm{H})$, 7.27-7.32 (m, 8H), 7.48-7.50 (m, 4H), 7.57-7.60 (m, 2H), $7.85\left(\mathrm{~d},{ }^{3} J=15.9 \mathrm{~Hz}, 2 \mathrm{H}\right), 8.04(\mathrm{~d}$, $\left.{ }^{3} J=15.9 \mathrm{~Hz}, 1 \mathrm{H}\right) \mathrm{ppm} .{ }^{13} \mathrm{C} \mathrm{NMR}\left(75 \mathrm{MHz}, \mathrm{CDCl}_{3}\right): \delta=40.4,112.2,112.3,122.6,123.7$, $124.76,124.78,125.2,128.7,129.2,129.5,129.8,135.8,138.0,147.4,148.9,151.0,163.0$, $165.4 \mathrm{ppm}$ All the atoms of carbon were not observed. IR (ATR): $v=3034,1564,1490$, 1361, 1273, 1167, 971, 810, 749, $692 \mathrm{~cm}^{-1}$. HR-MALDI-MS (DCTB): m/z calculated for $\mathrm{C}_{54} \mathrm{H}_{45} \mathrm{~N}_{5}\left[\mathrm{M}^{+}\right]$763.3670, found 763.3673.

(E,E,E)-2-(4-Diphenylaminostyryl)-4,6-bis(4-methoxystyryl)pyrimidine (2k). Synthesized from $1 \mathbf{1 d}(70 \mathrm{mg}, 0.19 \mathrm{mmol})$ and 4-methoxybenzaldehyde $(51 \mathrm{mg}, 0.37 \mathrm{mmol})$ following the general procedure for Knoevenagel condensation. The crude product was purified by column chromatography $\left(\mathrm{SiO}_{2}\right.$, petroleum ether:EtOAc, 8:2). Yield: $83 \mathrm{mg}(73 \%)$; yellow solid. $R_{\mathrm{f}}$ : 
$0.5\left(\mathrm{SiO}_{2}\right.$; petroleum ether:EtOAc, 8:2). $T_{\mathrm{d}}: 310{ }^{\circ} \mathrm{C} .{ }^{1} \mathrm{H}$ NMR $\left(300 \mathrm{MHz}, \mathrm{CDCl}_{3}\right): \delta=3.86(\mathrm{~s}$, 6H), 6.93-7.20 (m, 16H), 7.27-7.32 (m, 4H), 7.53-7.60 (m, 6H), $7.87\left(\mathrm{~d},{ }^{3} J=15.9 \mathrm{~Hz}, 2 \mathrm{H}\right)$, $8.05\left(\mathrm{~d},{ }^{3} \mathrm{~J}=15.9 \mathrm{~Hz}, 1 \mathrm{H}\right) \mathrm{ppm} .{ }^{13} \mathrm{C} \mathrm{NMR}\left(75 \mathrm{MHz}, \mathrm{CDCl}_{3}\right): \delta=55.5,112.8,114.4,122.8$, $123.6,124.5,126.4,128.8,128.9,129.2,129.5,130.3,136.1,137.2,147.5,148.6,160.7$, 163.1, 164.9 ppm. IR (ATR): $v=3033,1562,1506,1279,1248,1031,972,808,752,695 \mathrm{~cm}^{-}$ ${ }^{1}$. HR-MALDI-MS (DCTB): $\mathrm{m} / \mathrm{z}$ calculated for $\mathrm{C}_{42} \mathrm{H}_{35} \mathrm{~N}_{3} \mathrm{O}_{2}\left[\mathrm{M}^{+}\right]$613.2724, found 613.2728. (E,E,E)-2-(4-Diphenylaminostyryl)-4,6-bis(4-dimethylaminostyryl)pyrimidine

(21).

Synthesized from 1d (70 mg, $0.19 \mathrm{mmol})$ and 4-N,N-dimethylaminobenzaldehyde (56 mg, $0.37 \mathrm{mmol}$ ) following the general procedure for Knoevenagel condensation. The crude product was purified by column chromatography $\left(\mathrm{SiO}_{2}\right.$, petroleum ether:EtOAc, 8:2) and then by recrystallization from $\mathrm{CH}_{2} \mathrm{Cl}_{2} / n$-heptane. Yield: $62 \mathrm{mg}(52 \%)$; yellow solid. $R_{\mathrm{f}}$ : $0.5\left(\mathrm{SiO}_{2}\right.$; petroleum ether:EtOAc, 8:2). $T_{\mathrm{d}}: 195{ }^{\circ} \mathrm{C} .{ }^{1} \mathrm{H}$ NMR $\left(300 \mathrm{MHz}, \mathrm{CDCl}_{3}\right): \delta=3.03(\mathrm{~s}, 12 \mathrm{H})$, 6.71-6.74 (m, 4H), $6.90\left(\mathrm{~d},{ }^{3} J=15.9 \mathrm{~Hz}, 2 \mathrm{H}\right), 7.03-7.08(\mathrm{~m}, 5 \mathrm{H}), 7.13-7.19(\mathrm{~m}, 5 \mathrm{H}), 7.28-$ $7.31(\mathrm{~m}, 4 \mathrm{H}), 7.52-7.55(\mathrm{~m}, 6 \mathrm{H}), 7.83\left(\mathrm{~d},{ }^{3} J=15.9 \mathrm{~Hz}, 2 \mathrm{H}\right), 8.03\left(\mathrm{~d},{ }^{3} J=15.9 \mathrm{~Hz}, 1 \mathrm{H}\right) \mathrm{ppm}$. ${ }^{13} \mathrm{C} \mathrm{NMR}\left(75 \mathrm{MHz}_{\mathrm{CDCl}}\right.$ ) $: \delta=40.4,112.0,112.2,122.1,122.9,123.5,124.3,125.1,126.8$, $128.7,129.2,129.5,130.5,136.6,136.8,147.5,148.4,151.2,163.3,164.7$ ppm. IR (ATR): $v$ $=2853,1602,1553,1492,1358,1276,974,808,751,696 \mathrm{~cm}^{-1}$. HR-MALDI-MS (DCTB): $\mathrm{m} / \mathrm{z}$ calculated for $\mathrm{C}_{44} \mathrm{H}_{41} \mathrm{~N}_{5}\left[\mathrm{M}^{+}\right]$639.3357, found 639.3359 .

(E,E,E)-2,4,6-Tris(4-diphenylaminostyryl)pyrimidine (2m). Synthesized from 1d (33 mg, $0.09 \mathrm{mmol}$ ) and 4-N,N-diphenylaminobenzaldehyde (48 $\mathrm{mg}, 0.17 \mathrm{mmol})$ following the general procedure for Knoevenagel condensation. The crude product was purified by recrystallization from $\mathrm{CH}_{2} \mathrm{Cl}_{2} / n$-heptane. Yield: $44 \mathrm{mg}$ (57\%); yellow solid. $R_{\mathrm{f}}$ : $0.8\left(\mathrm{SiO}_{2}\right.$; petroleum ether:EtOAc, 8:2). $T_{\mathrm{d}}: 310{ }^{\circ} \mathrm{C} .{ }^{1} \mathrm{H}$ NMR $\left(300 \mathrm{MHz}, \mathrm{CDCl}_{3}\right): \delta=6.97\left(\mathrm{~d},{ }^{3} J=15.9\right.$ $\mathrm{Hz}, 2 \mathrm{H}), 7.04-7.20(\mathrm{~m}, 26 \mathrm{H}), 7.27-7.32(\mathrm{~m}, 12 \mathrm{H}), 7.47-7.55(\mathrm{~m}, 6 \mathrm{H}), 7.85\left(\mathrm{~d},{ }^{3} J=15.9 \mathrm{~Hz}\right.$, 2H), $8.04\left(\mathrm{~d},{ }^{3} \mathrm{~J}=15.9 \mathrm{~Hz}, 1 \mathrm{H}\right) \mathrm{ppm} .{ }^{13} \mathrm{C} \mathrm{NMR}\left(75 \mathrm{MHz}, \mathrm{CDCl}_{3}\right): \delta=112.7,122.6,122.8$, 
$123.5,123.7,124.3,124.6,125.1,125.2,126.4,128.7,129.49,129.54,129.6,130.3,136.0$, 137.2, 147.3, 147.5, 148.6, 148.9, 163.0, 164.9 ppm. IR (ATR): $v=3034,1588,1558,1489$, 1273, 1174, 970, 750, $693 \mathrm{~cm}^{-1}$. HR-MALDI-MS (DCTB): $\mathrm{m} / \mathrm{z}$ calculated for $\mathrm{C}_{64} \mathrm{H}_{49} \mathrm{~N}_{5}\left[\mathrm{M}^{+}\right]$ 887.3983, found 887.3982 .

(E,E,E)-2-[(6-Methoxynaphtalen-2-yl)ethenyl]-4,6-bis(4-methoxystyryl)pyrimidine (2n). Synthesized from 1e (56 mg, $0.19 \mathrm{mmol})$ and 4-methoxybenzaldehyde (52 $\mathrm{mg}, 0.38 \mathrm{mmol})$ following the general procedure for Knoevenagel condensation. The crude product was purified by recrystallization from $\mathrm{CH}_{2} \mathrm{Cl}_{2} / n$-heptane. Yield: $77 \mathrm{mg}(77 \%)$; yellowish solid. $R_{\mathrm{f}}$ : $0.3\left(\mathrm{SiO}_{2}\right.$; petroleum ether:EtOAc, 8:2). $T_{\mathrm{d}}: 290{ }^{\circ} \mathrm{C} .{ }^{1} \mathrm{H}$ NMR $\left(300 \mathrm{MHz}, \mathrm{CDCl}_{3}\right): \delta=3.86(\mathrm{~s}$, 6H), $3.94(\mathrm{~s}, 3 \mathrm{H}), 6.94-7.19(\mathrm{~m}, 9 \mathrm{H}), 7.38\left(\mathrm{~d},{ }^{3} J=15.9 \mathrm{~Hz}, 1 \mathrm{H}\right), 7.59-7.61(\mathrm{~m}, 4 \mathrm{H}), 7.74-$ $7.98(\mathrm{~m}, 6 \mathrm{H}), 8.24\left(\mathrm{~d},{ }^{3} J=15.9 \mathrm{~Hz}, 1 \mathrm{H}\right) \mathrm{ppm} .{ }^{13} \mathrm{C} \mathrm{NMR}\left(75 \mathrm{MHz}, \mathrm{CDCl}_{3}\right): \delta=55.5,106.1$, $113.1,114.5,119.2,124.5,124.8,127.4,127.8,128.6,128.9,129.1,129.2,130.0,132.1$, $135.1,136.2,137.9,158.4,160.7,163.1,164.7 \mathrm{ppm} . \mathrm{IR}(\mathrm{ATR}): v=2935,1601,1559,1505$, 1366, 1246, 1169, 1027, 959, 838, $809 \mathrm{~cm}^{-1}$. HR-MALDI-MS (DCTB): m/z calculated for $\mathrm{C}_{35} \mathrm{H}_{30} \mathrm{~N}_{2} \mathrm{O}_{3}\left[\mathrm{M}^{+}\right]$526.2251, found 526.2252.

\section{$(E, E, E)-2-[(6-M e t h o x y n a p h t a l e n-2-y l) e t h e n y l]-4,6-b i s(4-$}

dimethylaminostyryl)pyrimidine (2o). Synthesized from 1e (53 mg, $0.18 \mathrm{mmol})$ and 4- $N, N$ dimethylaminobenzaldehyde $(54 \mathrm{mg}, 0.36 \mathrm{mmol})$ following the general procedure for Knoevenagel condensation. The crude product was purified by recrystallization from $\mathrm{CH}_{2} \mathrm{Cl}_{2} / n$-heptane. Yield: $70 \mathrm{mg}(70 \%)$; orange solid. $R_{\mathrm{f}}: 0.2\left(\mathrm{SiO}_{2}\right.$; petroleum ether:EtOAc, 8:2). $T_{\mathrm{d}}: 250{ }^{\circ} \mathrm{C} .{ }^{1} \mathrm{H}$ NMR $\left(300 \mathrm{MHz}, \mathrm{CDCl}_{3}\right): \delta=3.03(\mathrm{~s}, 12 \mathrm{H}), 3.94(\mathrm{~s}, 3 \mathrm{H}), 6.72-6.75(\mathrm{~m}$, 4H), $6.92\left(\mathrm{~d},{ }^{3} J=15.9 \mathrm{~Hz}, 2 \mathrm{H}\right), 7.07-7.18(\mathrm{~m}, 3 \mathrm{H}), 7.38\left(\mathrm{~d},{ }^{3} J=15.9 \mathrm{~Hz}, 1 \mathrm{H}\right), 7.54-7.57$ (m, 4H), 7.74-7.90 (m, 5H), $7.99(\mathrm{~s}, 1 \mathrm{H}), 8.23\left(\mathrm{~d},{ }^{3} \mathrm{~J}=15.9 \mathrm{~Hz}, 1 \mathrm{H}\right) \mathrm{ppm} .{ }^{13} \mathrm{C}$ NMR $(75 \mathrm{MHz}$, $\left.\mathrm{CDCl}_{3}\right): \delta=40.4,55.5,106.1,112.2,112.3,119.1,122.0,124.3,124.8,127.3,128.2,128.4$, $129.2,130.0,132.2,135.0,136.7,137.4,151.2,158.3,163.4,164.5 \mathrm{ppm}$ All the atoms of 
carbon were not observed. IR (ATR): $v=2853,1600,1552,1357,1144,969,851,804 \mathrm{~cm}^{-1}$. HR-MALDI-MS (DCTB): m/z calculated for $\mathrm{C}_{37} \mathrm{H}_{36} \mathrm{~N}_{4} \mathrm{O}\left[\mathrm{M}^{+}\right]$552.2884, found 552.2889.

$(E, E, E)-2-[(6-M e t h o x y n a p h t a l e n-2-y l) e t h e n y l]-4,6-b i s(4-$

diphenylaminostyryl)pyrimidine (2p). Synthesized from 1 e (37 mg, $0.12 \mathrm{mmol})$ and 4- $N, N$ diphenylaminobenzaldehyde $(69 \mathrm{mg}, 0.25 \mathrm{mmol})$ following the general procedure for Knoevenagel condensation. The crude product was purified by recrystallization from $\mathrm{CH}_{2} \mathrm{Cl}_{2} / n$-heptane. Yield: $30 \mathrm{mg}(30 \%)$; orange solid. $R_{\mathrm{f}}: 0.6\left(\mathrm{SiO}_{2}\right.$; petroleum ether:EtOAc, 8:2). $T_{\mathrm{d}}: 220{ }^{\circ} \mathrm{C} .{ }^{1} \mathrm{H}$ NMR $\left(300 \mathrm{MHz}, \mathrm{CDCl}_{3}\right): \delta=3.94(\mathrm{~s}, 3 \mathrm{H}), 6.97-7.17(\mathrm{~m}, 22 \mathrm{H}), 7.28-$ $7.40(\mathrm{~m}, 8 \mathrm{H}), 7.49-7.52(\mathrm{~m}, 4 \mathrm{H}), 7.74-7.79(\mathrm{~m}, 2 \mathrm{H}), 7.84-7.92(\mathrm{~m}, 3 \mathrm{H}), 7.98(\mathrm{~s}, 1 \mathrm{H}), 8.23(\mathrm{~d}$, $\left.{ }^{3} J=15.9 \mathrm{~Hz}, 1 \mathrm{H}\right) \mathrm{ppm} .{ }^{13} \mathrm{C} \mathrm{NMR}\left(75 \mathrm{MHz}, \mathrm{CDCl}_{3}\right): \delta=55.5,106.1,113.0,119.2,122.6$, $123.8,124.5,124.8,125.2,127.4,127.8,128.6,128.8,129.1,129.5,129.6,130.0,132.1$, $135.1,136.1,137.8,147.4,149.0,158.4,163.1,164.8$ ppm. IR (ATR): $v=3034,1588,1558$, 1490, 1268, 1174, 969, 849, 751, $694 \mathrm{~cm}^{-1}$. HR-MALDI-MS (DCTB): m/z calculated for $\mathrm{C}_{57} \mathrm{H}_{44} \mathrm{~N}_{4} \mathrm{O}\left[\mathrm{M}^{+}\right]$800.3510, found 800.3518.

\section{(E,E,E)-2-(4-Trifluoromethylstyryl)-4,6-bis(4-methoxystyryl)pyrimidine}

(2q).

Synthesized from 1f $(90 \mathrm{mg}, 0.32 \mathrm{mmol})$ and 4-methoxybenzaldehyde ( $88 \mathrm{mg}, 0.65 \mathrm{mmol})$ following the general procedure for Knoevenagel condensation. The crude product was purified by column chromatography $\left(\mathrm{SiO}_{2}\right.$, petroleum ether:EtOAc, 7:3). Yield: $71 \mathrm{mg}$ (43 $\%)$; yellowish solid. $R_{\mathrm{f}}: 0.7\left(\mathrm{SiO}_{2}\right.$; petroleum ether:EtOAc, 7:3). $T_{\mathrm{d}}: 280{ }^{\circ} \mathrm{C} .{ }^{1} \mathrm{H}$ NMR $(300$ $\left.\mathrm{MHz}, \mathrm{CDCl}_{3}\right): \delta=3.86(\mathrm{~s}, 6 \mathrm{H}), 6.94-7.02(\mathrm{~m}, 6 \mathrm{H}), 7.13(\mathrm{~s}, 1 \mathrm{H}), 7.38\left(\mathrm{~d},{ }^{3} J=15.9 \mathrm{~Hz}, 1 \mathrm{H}\right)$, 7.58-7.61 (m, 4H), 7.65-7.68 (m, 2H), 7.76-7.79 (m, 2H), $7.91\left(\mathrm{~d},{ }^{3} J=15.9 \mathrm{~Hz}, 2 \mathrm{H}\right), 8.11(\mathrm{~d}$, $\left.{ }^{3} J=15.9 \mathrm{~Hz}, 1 \mathrm{H}\right) \mathrm{ppm} .{ }^{13} \mathrm{C} \mathrm{NMR}\left(75 \mathrm{MHz}, \mathrm{CDCl}_{3}\right): \delta=55.5,113.6,114.5,124.2,124.3$ (q, $\left.{ }^{1} J_{\mathrm{CF}}=270 \mathrm{~Hz}\right), 125.8\left(\mathrm{q},{ }^{3} J_{\mathrm{CF}}=4 \mathrm{~Hz}\right), 127.8,128.8,129.3,130.4\left(\mathrm{q},{ }^{2} J_{\mathrm{CF}}=32 \mathrm{~Hz}\right), 131.1$, 135.8, 136.5, 140.1, 160.8, 163.2, 163.9 ppm. IR (ATR): $v=2838,1568,1325,1251,1107$, 
976, $818 \mathrm{~cm}^{-1}$. HR-MALDI-MS (DCTB): $\mathrm{m} / \mathrm{z}$ calculated for $\mathrm{C}_{31} \mathrm{H}_{25} \mathrm{~F}_{3} \mathrm{~N}_{2} \mathrm{O}_{2}\left[\mathrm{M}^{+}\right]$514.1863, found 514.1861.

\section{(E,E,E)-2-(4-Trifluoromethylstyryl)-4,6-bis(4-dimethylaminostyryl)pyrimidine}

(2r).

Synthesized from 1f (90 mg, $0.32 \mathrm{mmol})$ and 4-N,N-dimethylaminobenzaldehyde (97 mg, $0.65 \mathrm{mmol}$ ) following the general procedure for Knoevenagel condensation. The crude product was purified by by column chromatography $\left(\mathrm{SiO}_{2}\right.$, petroleum ether:EtOAc, 8:2). Yield: $69 \mathrm{mg}$ (40\%); orange solid. $R_{\mathrm{f}}: 0.3\left(\mathrm{SiO}_{2}\right.$; petroleum ether:EtOAc, 8:2). Mp: $210{ }^{\circ} \mathrm{C}$. ${ }^{1} \mathrm{H}$ NMR $\left(300 \mathrm{MHz}, \mathrm{CDCl}_{3}\right): \delta=3.04(\mathrm{~s}, 12 \mathrm{H}), 6.72-6.75(\mathrm{~m}, 4 \mathrm{H}), 6.91\left(\mathrm{~d},{ }^{3} J=15.9 \mathrm{~Hz}\right.$, 2H), $7.10(\mathrm{~s}, 1 \mathrm{H}), 7.37\left(\mathrm{~d},{ }^{3} J=15.9 \mathrm{~Hz}, 1 \mathrm{H}\right), 7.53-7.56(\mathrm{~m}, 4 \mathrm{H}), 7.64-7.67(\mathrm{~m}, 2 \mathrm{H}), 7.76-$ $7.79(\mathrm{~m}, 2 \mathrm{H}), 7.86\left(\mathrm{~d},{ }^{3} \mathrm{~J}=15.9 \mathrm{~Hz}, 2 \mathrm{H}\right), 8.09\left(\mathrm{~d},{ }^{3} \mathrm{~J}=15.9 \mathrm{~Hz}, 1 \mathrm{H}\right) \mathrm{ppm} .{ }^{13} \mathrm{C}$ NMR $(75 \mathrm{MHz}$, $\left.\mathrm{CDCl}_{3}\right): \delta=40.4,112.2,112.9,121.7,124.1,124.3\left(\mathrm{q},{ }^{1} J_{\mathrm{CF}}=270 \mathrm{~Hz}\right), 125.8\left(\mathrm{q},{ }^{3} J_{\mathrm{CF}}=4 \mathrm{~Hz}\right)$, $127.8,129.2,130.2\left(\mathrm{q},{ }^{2} J_{\mathrm{CF}}=32 \mathrm{~Hz}\right), 131.4,135.4,137.0,140.2,151.2,163.5,163.8$ ppm. IR (ATR): $v=2892,1494,1318,1116,1065,974,809 \mathrm{~cm}^{-1}$. HR-MALDI-MS (DCTB): m/z calculated for $\mathrm{C}_{33} \mathrm{H}_{31} \mathrm{~F}_{3} \mathrm{~N}_{4}\left[\mathrm{M}^{+}\right]$540.2495, found 540.2501.

\section{(E,E,E)-2-(4-Trifluoromethylstyryl)-4,6-bis(4-diphenylaminostyryl)pyrimidine}

(2s).

Synthesized from 1f (90 mg, $0.32 \mathrm{mmol})$ and 4-N,N-diphenylaminobenzaldehyde (177 mg, $0.65 \mathrm{mmol}$ ) following the general procedure for Knoevenagel condensation. The crude product was purified by column chromatography $\left(\mathrm{SiO}_{2}\right.$, petroleum ether:EtOAc, 9:1). Yield: $70 \mathrm{mg}$ (28\%); yellow solid. $R_{\mathrm{f}}: 0.7\left(\mathrm{SiO}_{2}\right.$; petroleum ether:EtOAc, 9:1). $T_{\mathrm{d}}: 300{ }^{\circ} \mathrm{C} .{ }^{1} \mathrm{H}$ NMR $\left(300 \mathrm{MHz}, \mathrm{CDCl}_{3}\right): \delta=7.00\left(\mathrm{~d},{ }^{3} J=15.9 \mathrm{~Hz}, 2 \mathrm{H}\right), 7.08-7.19(\mathrm{~m}, 18 \mathrm{H}), 7.30-7.43(\mathrm{~m}, 8 \mathrm{H})$, $7.50-7.53(\mathrm{~m}, 4 \mathrm{H}), 7.66-7.69(\mathrm{~m}, 2 \mathrm{H}), 7.78-7.80(\mathrm{~m}, 2 \mathrm{H}), 7.90\left(\mathrm{~d},{ }^{3} J=15.9 \mathrm{~Hz}, 2 \mathrm{H}\right), 8.12(\mathrm{~d}$, $\left.{ }^{3} J=15.9 \mathrm{~Hz}, 1 \mathrm{H}\right) \mathrm{ppm} .{ }^{13} \mathrm{C} \mathrm{NMR}\left(75 \mathrm{MHz}, \mathrm{CDCl}_{3}\right): \delta=113.6,123.8,124.0,124.1,124.5(\mathrm{q}$, $\left.{ }^{1} J_{\mathrm{CF}}=276 \mathrm{~Hz}\right), 125.3,125.8\left(\mathrm{q},{ }^{3} J_{\mathrm{CF}}=4 \mathrm{~Hz}\right), 127.8,128.8,129.4,129.6,130.4\left(\mathrm{q},{ }^{2} J_{\mathrm{CF}}=32\right.$ $\mathrm{Hz}), 131.1,135.7,136.3,140.0\left(\mathrm{q},{ }^{4} J_{\mathrm{CF}}=1 \mathrm{~Hz}\right), 147.3,149.1,163.2,163.9$ ppm. IR (ATR): $v$ 
$=3033,1559,1490,1320,1066,968,751 \mathrm{~cm}^{-1}$. HR-MALDI-MS (DCTB): m/z calculated for $\mathrm{C}_{53} \mathrm{H}_{39} \mathrm{~F}_{3} \mathrm{~N}_{4}\left[\mathrm{M}^{+}\right]$788.3121, found 788.3111.

(E)-2-Chloro-4-(4-dimethylaminostyryl)-6-methylpyrimidine (3a). Synthesized from 4ethynyl- $N, N$-dimethylaniline $(250 \mathrm{mg}, 1.72 \mathrm{mmol})$ and 2,4-dichloro-6-methylpyrimidine (179 mg, $1.1 \mathrm{mmol}$ ) following the general procedure for Suzuki-Miyaura reaction. The crude product was purified by column chromatography $\left(\mathrm{SiO}_{2}\right.$, petroleum ether:EtOAc, 8:2). Yield: $156 \mathrm{mg}$ (52\%); brown solid. $R_{\mathrm{f}}: 0.4\left(\mathrm{SiO}_{2}\right.$; petroleum ether:EtOAc, 8:2). Mp: 163.4-165.7 ${ }^{\circ} \mathrm{C} .{ }^{1} \mathrm{H}$ NMR $\left(300 \mathrm{MHz}, \mathrm{CDCl}_{3}\right): \delta=2.49(\mathrm{~s}, 3 \mathrm{H}), 3.03(\mathrm{~s}, 6 \mathrm{H}), 6.68-6.78(\mathrm{~m}, 3 \mathrm{H}), 6.99$ (s, 1H), 7.47-7.50 (m, 2H), $7.83\left(\mathrm{~d},{ }^{3} J=15.9 \mathrm{~Hz}, 1 \mathrm{H}\right) \mathrm{ppm} .{ }^{13} \mathrm{C} \mathrm{NMR}\left(75 \mathrm{MHz}, \mathrm{CDCl}_{3}\right): \delta=$ $24.0,40.3,112.1,115.6,119.2,123.3,129.6,139.5,151.6,161.1,166.2,169.9$ ppm. IR (ATR): $v=2913,2193,1566,1258,979,809,750,765 \mathrm{~cm}^{-1}$. HR-MALDI-MS (DCTB): m/z calculated for $\mathrm{C}_{15} \mathrm{H}_{16} \mathrm{ClN}_{3}\left[\mathrm{M}^{+}\right] 273.1027$, found 273.1023 .

(E)-2-Chloro-4-(4-methoxystyryl)-6-methylpyrimidine $\quad(3 b) . \quad$ Synthesized from 4ethynylanisole (311 mg, $2.35 \mathrm{mmol})$ and 2,4-dichloro-6-methylpyrimidine (245 mg, 1.5 mmol) following the general procedure for Suzuki-Miyaura reaction. The crude product was purified by column chromatography $\left(\mathrm{SiO}_{2}\right.$, petroleum ether:EtOAc, 7:3). Yield: $215 \mathrm{mg}$ (55 \%); yellowish solid. $R_{\mathrm{f}}$ : $0.4\left(\mathrm{SiO}_{2}\right.$; petroleum ether:EtOAc, 7:3). Mp: 78.9-81.8 ${ }^{\circ} \mathrm{C} .{ }^{1} \mathrm{H}$ NMR $\left(300 \mathrm{MHz}, \mathrm{CDCl}_{3}\right): \delta=2.51(\mathrm{~s}, 3 \mathrm{H}), 3.85(\mathrm{~s}, 3 \mathrm{H}), 6.83\left(\mathrm{~d},{ }^{3} J=15.9 \mathrm{~Hz}, 1 \mathrm{H}\right), 6.90-6.95(\mathrm{~m}$, 2H), $7.04(\mathrm{~s}, 1 \mathrm{H}), 7.51-7.56(\mathrm{~m}, 2 \mathrm{H}), 7.86\left(\mathrm{~d},{ }^{3} \mathrm{~J}=15.9 \mathrm{~Hz}, 1 \mathrm{H}\right) \mathrm{ppm} .{ }^{13} \mathrm{C}$ NMR $(75 \mathrm{MHz}$, $\left.\mathrm{CDCl}_{3}\right): \delta=24.1,55.5,114.6,116.2,122.0,128.2,129.6,138.7,161.18,161.21,165.6,170.5$ ppm. IR (ATR): $v=2924,1570,1512,1256,1178,1020,967,819 \mathrm{~cm}^{-1}$. HR-MALDI-MS (DCTB): $\mathrm{m} / \mathrm{z}$ calculated for $\mathrm{C}_{14} \mathrm{H}_{13} \mathrm{ClN}_{2} \mathrm{O}\left[\mathrm{M}^{+}\right]$260.0711, found 260.0710.

\section{(E,E)-2-(4-Methoxystyryl)-4-(4-dimethylaminostyryl)-6-methylpyrimidine}

(4a).

Synthesized from 4-ethynylanisole $(91 \mathrm{mg}, 0.69 \mathrm{mmol})$ and 3a $(120 \mathrm{mg}, 0.44 \mathrm{mmol})$ following the general procedure for Suzuki-Miyaura reaction. The crude product was purified 
by column chromatography $\left(\mathrm{SiO}_{2}\right.$, petroleum ether:EtOAc, 7:3). Yield: $65 \mathrm{mg}$ (40\%); orange solid. $R_{\mathrm{f}}: 0.3\left(\mathrm{SiO}_{2}\right.$; petroleum ether:EtOAc, 7:3). Mp: 79.9-81.5 ${ }^{\circ} \mathrm{C} .{ }^{1} \mathrm{H}$ NMR $(300 \mathrm{MHz}$, $\left.\mathrm{CDCl}_{3}\right): \delta=2.51(\mathrm{~s}, 3 \mathrm{H}), 3.02(\mathrm{~s}, 6 \mathrm{H}), 3.84(\mathrm{~s}, 3 \mathrm{H}), 6.70-6.73(\mathrm{~m}, 2 \mathrm{H}), 6.83-6.94(\mathrm{~m}, 4 \mathrm{H})$, $7.13\left(\mathrm{~d},{ }^{3} J=15.9 \mathrm{~Hz}, 1 \mathrm{H}\right), 7.50-7.53(\mathrm{~m}, 2 \mathrm{H}), 7.58-7.61(\mathrm{~m}, 2 \mathrm{H}), 7.81\left(\mathrm{~d},{ }^{3} J=15.9 \mathrm{~Hz}, 1 \mathrm{H}\right)$, $7.99\left(\mathrm{~d},{ }^{3} J=15.9 \mathrm{~Hz}, 1 \mathrm{H}\right) \mathrm{ppm} .{ }^{13} \mathrm{C} \mathrm{NMR}\left(75 \mathrm{MHz}, \mathrm{CDCl}_{3}\right): \delta=24.3,40.4,55.4,112.2$, $114.3,114.4,121.6,124.1,126.1,129.1,129.2,129.4,137.1,151.2,160.3,163.2,164.6$, $166.7 \mathrm{ppm}$ All the atoms of carbon were not observed. IR (ATR): $v=2922,1602,1509$, 1352, 1242, 1169, 973, $809 \mathrm{~cm}^{-1}$. HR-MALDI-MS (DCTB): $\mathrm{m} / \mathrm{z}$ calculated for $\mathrm{C}_{24} \mathrm{H}_{25} \mathrm{~N}_{3} \mathrm{O}$ $\left[\mathrm{M}^{+}\right]$371.1992, found 371.1988.

(E,E)-2-(4-Dimethylaminostyryl)-4-(4-methoxystyryl)-6-methylpyrimidine

(4b).

Synthesized from 4-ethynyl- $N, N$-dimethylaniline $(155 \mathrm{mg}, 1.06 \mathrm{mmol})$ and $\mathbf{3 b}(177 \mathrm{mg}, 0.68$ mmol) following the general procedure for Suzuki-Miyaura reaction. The crude product was purified by column chromatography $\left(\mathrm{SiO}_{2}\right.$, petroleum ether:EtOAc, 7:3). Yield: $190 \mathrm{mg}$ (75 \%); brown solid. $R_{\mathrm{f}}: 0.2\left(\mathrm{SiO}_{2}\right.$; petroleum ether:EtOAc, 7:3). Mp: $123.5-125.7{ }^{\circ} \mathrm{C} .{ }^{1} \mathrm{H}$ NMR $\left(300 \mathrm{MHz}, \mathrm{CDCl}_{3}\right): \delta=2.52(\mathrm{~s}, 3 \mathrm{H}), 3.01(\mathrm{~s}, 6 \mathrm{H}), 3.84(\mathrm{~s}, 3 \mathrm{H}), 6.70-6.73(\mathrm{~m}, 2 \mathrm{H}), 6.90-6.95$ (m, 4H), $7.07\left(\mathrm{~d},{ }^{3} J=15.9 \mathrm{~Hz}, 1 \mathrm{H}\right), 7.54-7.58(\mathrm{~m}, 4 \mathrm{H}), 7.83\left(\mathrm{~d},{ }^{3} J=15.9 \mathrm{~Hz}, 1 \mathrm{H}\right), 7.99\left(\mathrm{~d},{ }^{3} J\right.$ $=15.9 \mathrm{~Hz}, 1 \mathrm{H}) \mathrm{ppm} .{ }^{13} \mathrm{C} \mathrm{NMR}\left(75 \mathrm{MHz}, \mathrm{CDCl}_{3}\right): \delta=24.4,40.4,55.5,112.2,114.3,114.4$, $123.3,124.4,124.6,128.9,129.1,136.0,138.1,151.0,160.6,162.5,165.2,166.9 \mathrm{ppm}$ All the atoms of carbon were not observed. IR (ATR): $v=2918,1599,1509,1351,1249,1162,970$, $808 \mathrm{~cm}^{-1}$. HR-MALDI-MS (DCTB): $\mathrm{m} / \mathrm{z}$ calculated for $\mathrm{C}_{24} \mathrm{H}_{25} \mathrm{~N}_{3} \mathrm{O}\left[\mathrm{M}^{+}\right]$371.1992, found 371.1993.

\section{(E,E,E)-2-(4-Methoxystyryl)-4-(4-dimethylaminostyryl)-6-(4-}

diphenylaminostyryl)pyrimidine (5a). Synthesized from $\mathbf{4 a}(45 \mathrm{mg}, 0.12 \mathrm{mmol})$ and 4- $N, N$ diphenylaminobenzaldehyde (33 $\mathrm{mg}, 0.12 \mathrm{mmol}$ ) following the general procedure for Knoevenagel condensation. The crude product was purified by column chromatography 
$\left(\mathrm{SiO}_{2}\right.$, petroleum ether:EtOAc, 8:2). Yield: $46 \mathrm{mg}(61 \%)$; orange solid. $R_{\mathrm{f}}: 0.5\left(\mathrm{SiO}_{2}\right.$; petroleum ether:EtOAc, 8:2). $T_{\mathrm{d}}: 240{ }^{\circ} \mathrm{C} .{ }^{1} \mathrm{H}$ NMR $\left(300 \mathrm{MHz}, \mathrm{CDCl}_{3}\right): \delta=3.03(\mathrm{~s}, 6 \mathrm{H}), 3.85$ (s, 3H), 6.71-6.74 (m, 2H), 6.88-7.20 (m, 14H), 7.27-7.32 (m, 4H), 7.48-7.55 (m, 4H), 7.62$7.65(\mathrm{~m}, 2 \mathrm{H}), 7.85\left(\mathrm{~d},{ }^{3} \mathrm{~J}=15.9 \mathrm{~Hz}, 2 \mathrm{H}\right), 8.05\left(\mathrm{~d},{ }^{3} \mathrm{~J}=15.9 \mathrm{~Hz}, 1 \mathrm{H}\right) \mathrm{ppm} .{ }^{13} \mathrm{C}$ NMR $(75 \mathrm{MHz}$, $\left.\mathrm{CDCl}_{3}\right): \delta=40.4,55.5,112.2,112.5,114.3,121.9,122.6,123.7,124.2,124.7,125.2,126.5$, $128.7,129.2,129.2,129.50,129.54,129.8,135.7,136.9,137.0,147.4,148.9,151.2,160.3$, 162.7, 163.6, 164.8 ppm. IR (ATR): $v=2925,1561,1490,1247,1170,1144,971,694 \mathrm{~cm}^{-1}$. HR-MALDI-MS (DCTB): m/z calculated for $\mathrm{C}_{43} \mathrm{H}_{38} \mathrm{~N}_{4} \mathrm{O}$ [M $\left.\mathrm{M}^{+}\right]$626.3040, found 626.3038 .

\section{(E,E,E)-2-(4-Dimethylaminostyryl)-4-(4-methoxystyryl)-6-(4-}

diphenylaminostyryl)pyrimidine (5b). Synthesized from $\mathbf{4 b}(150 \mathrm{mg}, 0.40 \mathrm{mmol})$ and 4$N, N$-diphenylaminobenzaldehyde $(110 \mathrm{mg}, 0.40 \mathrm{mmol})$ following the general procedure for Knoevenagel condensation. The crude product was purified by column chromatography $\left(\mathrm{SiO}_{2}\right.$, petroleum ether:EtOAc, 7:3). Yield: $84 \mathrm{mg}$ (33\%); orange solid. $R_{\mathrm{f}}: 0.5\left(\mathrm{SiO}_{2}\right.$; petroleum ether:EtOAc, 7:3). $T_{\mathrm{d}}: 210{ }^{\circ} \mathrm{C} .{ }^{1} \mathrm{H}$ NMR (300 MHz, $\left.\mathrm{CDCl}_{3}\right): \delta=3.02(\mathrm{~s}, 6 \mathrm{H}), 3.85$ (s, 3H), 6.72-6.75 (m, 2H), 6.93-7.16 (m, 14H), 7.27-7.32 (m, 4H), 7.48-7.51 (m, 2H), 7.57$7.60(\mathrm{~m}, 4 \mathrm{H}), 7.82-7.90(\mathrm{~m}, 2 \mathrm{H}), 8.05\left(\mathrm{~d},{ }^{3} J=15.9 \mathrm{~Hz}, 1 \mathrm{H}\right)$ ppm. ${ }^{13} \mathrm{C}$ NMR $(75 \mathrm{MHz}$, $\left.\mathrm{CDCl}_{3}\right): \delta=40.4,55.5,112.3,112.3,114.4,122.6,123.7,124.2,124.4,124.7,124.8,125.2$, $128.4,128.7,129.0,129.2,129.4,129.5,129.8,135.9,138.1,147.4,148.9,151.0,160.6$, 162.9, 163.0, 165.4 ppm. IR (ATR): $v=2921,1500,1359,1248,1166,971,809,693 \mathrm{~cm}^{-1}$. HR-MALDI-MS (DCTB): m/z calculated for $\mathrm{C}_{43} \mathrm{H}_{38} \mathrm{~N}_{4} \mathrm{O}$ [M $\left.{ }^{+}\right]$626.3040, found 626.3058 .

(E)-2-Styryl-4-methylpyrimidine (6a). Synthesized from phenylacetylene (176 mg, 1.72 $\mathrm{mmol}$ ) and 2-chloro-4-methylpyrimidine (142 $\mathrm{mg}, 1.1 \mathrm{mmol})$ following the general procedure for Suzuki-Miyaura reaction. The crude product was purified by column chromatography $\left(\mathrm{SiO}_{2}\right.$, petroleum ether:EtOAc, 8:2). Yield: $70 \mathrm{mg}(32 \%)$; white solid. $R_{\mathrm{f}}: 0.4\left(\mathrm{SiO}_{2}\right.$; petroleum ether:EtOAc, 8:2). Mp: 67.2-69.9 ${ }^{\circ} \mathrm{C}\left(\right.$ lit. $^{32}$ 65-67 $\left.{ }^{\circ} \mathrm{C}\right) .{ }^{1} \mathrm{H} \mathrm{NMR}\left(300 \mathrm{MHz}, \mathrm{CDCl}_{3}\right)$ : 
$\delta=2.54(\mathrm{~s}, 3 \mathrm{H}), 6.97\left(\mathrm{~d},{ }^{3} J=4.8 \mathrm{~Hz}, 1 \mathrm{H}\right), 7.22\left(\mathrm{~d},{ }^{3} J=15.9 \mathrm{~Hz}, 1 \mathrm{H}\right), 7.30-7.41(\mathrm{~m}, 3 \mathrm{H})$, $7.61-7.63(\mathrm{~m}, 2 \mathrm{H}), 7.98\left(\mathrm{~d},{ }^{3} J=15.9 \mathrm{~Hz}, 1 \mathrm{H}\right), 8.56\left(\mathrm{~d},{ }^{3} J=4.8 \mathrm{~Hz}, 1 \mathrm{H}\right) \mathrm{ppm} .{ }^{13} \mathrm{C}$ NMR $(75$ $\left.\mathrm{MHz}, \mathrm{CDCl}_{3}\right): \delta=24.4,118.3,127.7,128.9,129.1,136.3,137.9,156.8,164.7,167.1$ ppm All the atoms of carbon were not observed. IR (ATR): $v=2918,1547,1440,1385,978,790,747$ $\mathrm{cm}^{-1}$. HR-MALDI-MS (DCTB): $\mathrm{m} / \mathrm{z}$ calculated for $\mathrm{C}_{13} \mathrm{H}_{13} \mathrm{~N}_{2}\left[(\mathrm{M}+\mathrm{H})^{+}\right] 197.1073$, found 197.1073.

\section{(E)-2-(4-Methoxystyryl)-4-methylpyrimidine (6b).}

Synthesized from 4-ethynylanisole $(311 \mathrm{mg}, 2.35 \mathrm{mmol})$ and 2-chloro-4-methylpyrimidine (193 mg, $1.50 \mathrm{mmol}$ ) following the general procedure for Suzuki-Miyaura reaction. The crude product was purified by column chromatography $\left(\mathrm{SiO}_{2}\right.$, petroleum ether:EtOAc, 7:3). Yield: $206 \mathrm{mg}$ (61\%); brownish solid. $R_{\mathrm{f}}: 0.2\left(\mathrm{SiO}_{2}\right.$; petroleum ether:EtOAc, 7:3). Mp: 102.3-104.9 ${ }^{\circ} \mathrm{C} .{ }^{1} \mathrm{H}$ NMR $\left(300 \mathrm{MHz}, \mathrm{CDCl}_{3}\right): \delta=2.53(\mathrm{~s}, 3 \mathrm{H}), 3.83(\mathrm{~s}, 3 \mathrm{H}), 6.90-6.95(\mathrm{~m}, 3 \mathrm{H}), 7.09\left(\mathrm{~d},{ }^{3} J\right.$ $=15.9 \mathrm{~Hz}, 1 \mathrm{H}), 7.55-7.58(\mathrm{~m}, 2 \mathrm{H}), 7.93\left(\mathrm{~d},{ }^{3} J=15.9 \mathrm{~Hz}, 1 \mathrm{H}\right), 8.54\left(\mathrm{~d},{ }^{3} J=5.1 \mathrm{~Hz}, 1 \mathrm{H}\right) \mathrm{ppm}$. ${ }^{13} \mathrm{C}$ NMR $\left(75 \mathrm{MHz}, \mathrm{CDCl}_{3}\right): \delta=24.4,55.5,114.4,117.9,125.5,129.1,129.2,137.6,156.7$, 160.6, 165.0, 167.1 ppm. IR (ATR): $v=2937,1566,1509,1249,1178,1028,981,821,775$ $\mathrm{cm}^{-1}$. HR-MALDI-MS (DCTB): $\mathrm{m} / \mathrm{z}$ calculated for $\mathrm{C}_{14} \mathrm{H}_{14} \mathrm{~N}_{2} \mathrm{O} \quad\left[\mathrm{M}^{+}\right]$226.1101, found 226.1100 .

\section{(E)-2-(4-Dimethylaminostyryl)-4-methylpyrimidine (6c).}

Synthesized from 4-ethynyl- $N, N$-dimethylaniline $(250 \mathrm{mg}, 1.72 \mathrm{mmol})$ and 2-chloro-4methylpyrimidine (142 mg, $1.1 \mathrm{mmol})$ following the general procedure for Suzuki-Miyaura reaction. The crude product was purified by column chromatography $\left(\mathrm{SiO}_{2}\right.$, petroleum ether:EtOAc, 8:2). Yield: $85 \mathrm{mg}$ (32\%); brown solid. $R_{\mathrm{f}}: 0.3\left(\mathrm{SiO}_{2}\right.$; petroleum ether:EtOAc, 8:2). Mp: $117.3-119.8^{\circ} \mathrm{C} .{ }^{1} \mathrm{H}$ NMR $\left(300 \mathrm{MHz}, \mathrm{CDCl}_{3}\right): \delta=2.51(\mathrm{~s}, 3 \mathrm{H}), 2.99(\mathrm{~s}, 6 \mathrm{H}), 6.68-$ $6.71(\mathrm{~m}, 2 \mathrm{H}), 6.89\left(\mathrm{~d},{ }^{3} J=5.1 \mathrm{~Hz}, 1 \mathrm{H}\right), 7.02\left(\mathrm{~d},{ }^{3} J=15.9 \mathrm{~Hz}, 1 \mathrm{H}\right), 7.49-7.52(\mathrm{~m}, 2 \mathrm{H}), 7.92$ $\left(\mathrm{d},{ }^{3} J=15.9 \mathrm{~Hz}, 1 \mathrm{H}\right), 8.50\left(\mathrm{~d},{ }^{3} J=5.1 \mathrm{~Hz}, 1 \mathrm{H}\right) \mathrm{ppm} .{ }^{13} \mathrm{C}$ NMR $\left(75 \mathrm{MHz}, \mathrm{CDCl}_{3}\right): \delta=24.3$, 
$40.3,112.2,117.3,122.6,124.3,129.2,138.5,151.1,156.5,165.3,166.9$ ppm. IR (ATR): $v=$ 2912, 1602, 1523, 1435, 1363, 1167, 987, 805, 768, $750 \mathrm{~cm}^{-1}$. HR-MALDI-MS (DCTB): m/z calculated for $\mathrm{C}_{15} \mathrm{H}_{17} \mathrm{~N}_{3}\left[\mathrm{M}^{+}\right]$239.1417, found 239.1415.

(E)-2-(4-Diphenylaminostyryl)-4-methylpyrimidine (6d). Synthesized from 4-ethynyl- $N, N$ diphenylaniline (275 mg, $1.02 \mathrm{mmol})$ and 2-chloro-4-methylpyrimidine (84 mg, $0.65 \mathrm{mmol})$ following the general procedure for Suzuki-Miyaura reaction. The crude product was purified by column chromatography $\left(\mathrm{SiO}_{2}\right.$, petroleum ether:EtOAc, 8:2). Yield: $102 \mathrm{mg}$ (43\%); yellow solid. $R_{\mathrm{f}}$ : 0.2 ( $\mathrm{SiO}_{2}$; petroleum ether:EtOAc, 8:2). Mp: $120.9-123.5{ }^{\circ} \mathrm{C} .{ }^{1} \mathrm{H}$ NMR (300 $\left.\mathrm{MHz}, \mathrm{CDCl}_{3}\right): \delta=2.53(\mathrm{~s}, 3 \mathrm{H}), 6.94\left(\mathrm{~d},{ }^{3} J=5.1 \mathrm{~Hz}, 1 \mathrm{H}\right), 7.02-7.15(\mathrm{~m}, 10 \mathrm{H}), 7.25-7.31(\mathrm{~m}$, 3H), 7.46-7.49 (m, 2H), $7.92\left(\mathrm{~d},{ }^{3} J=15.9 \mathrm{~Hz}, 1 \mathrm{H}\right), 8.54\left(\mathrm{~d},{ }^{3} J=5.1 \mathrm{~Hz}, 1 \mathrm{H}\right) \mathrm{ppm} .{ }^{13} \mathrm{C}$ NMR $\left(75 \mathrm{MHz}, \mathrm{CDCl}_{3}\right): \delta=24.4,117.9,122.6,123.6,125.2,125.4,128.7,129.5,129.8,137.6$, 147.4, 148.8, 156.7, 165.0, 167.1 ppm. IR (ATR): $v=3036,1572,1487,1266,984,831,750$, $695 \mathrm{~cm}^{-1}$. HR-MALDI-MS (DCTB): $\mathrm{m} / \mathrm{z}$ calculated for $\mathrm{C}_{25} \mathrm{H}_{21} \mathrm{~N}_{3}\left[\mathrm{M}^{+}\right]$363.1730, found 363.1723 .

(E,E)-2,4-Distyrylpyrimidine (7a). Synthesized from 6a $(50 \mathrm{mg}, 0.25 \mathrm{mmol})$ and benzaldehyde $(28 \mathrm{mg}, 0.25 \mathrm{mmol})$ following the general procedure for Knoevenagel condensation. The crude product was purified by column chromatography $\left(\mathrm{SiO}_{2}\right.$; petroleum ether:EtOAc, 8:2). Yield: $41 \mathrm{mg}(57 \%)$; white solid. $R_{\mathrm{f}}$ : $0.4\left(\mathrm{SiO}_{2}\right.$; petroleum ether:EtOAc, 8:2). Mp: $137{ }^{\circ} \mathrm{C} .{ }^{1} \mathrm{H}$ NMR (300 MHz, $\left.\mathrm{CDCl}_{3}\right): \delta=7.08-7.15(\mathrm{~m}, 2 \mathrm{H}), 7.32-7.41(\mathrm{~m}, 7 \mathrm{H})$, $7.63-7.68(\mathrm{~m}, 4 \mathrm{H}), 7.92\left(\mathrm{~d},{ }^{3} J=15.9 \mathrm{~Hz}, 1 \mathrm{H}\right), 8.05\left(\mathrm{~d},{ }^{3} J=15.9 \mathrm{~Hz}, 1 \mathrm{H}\right), 8.67\left(\mathrm{~d},{ }^{3} J=5.1 \mathrm{~Hz}\right.$, 1H) ppm. ${ }^{13} \mathrm{C}$ NMR $\left(75 \mathrm{MHz}, \mathrm{CDCl}_{3}\right): \delta=115.9,126.3,127.8,128.0,128.9,129.0,129.1$, $129.5,135.9,136.3,137.2,138.1,157.6,162.5,164.9 \mathrm{ppm}$ All the atoms of carbon were not observed. IR (ATR): $v=3054,3026,1637,1558,1537,1388,975,876,738,688 \mathrm{~cm}^{-1} . \mathrm{HR}-$ MALDI-MS (DCTB): m/z calculated for $\mathrm{C}_{20} \mathrm{H}_{17} \mathrm{~N}_{2}\left[(\mathrm{M}+\mathrm{H})^{+}\right]$285.1386, found 285.1385. 
(E,E)-2,4-Bis(4-methoxystyryl)pyrimidine (7b). Synthesized from $6 \mathbf{b}(170 \mathrm{mg}, 0.75 \mathrm{mmol})$ and 4-methoxybenzaldehyde $(103 \mathrm{mg}, 0.75 \mathrm{mmol})$ following the general procedure for Knoevenagel condensation. The crude product was purified by recrystallization from $\mathrm{CH}_{2} \mathrm{Cl}_{2} / n$-heptane. Yield: $218 \mathrm{mg}(84 \%)$; silver solid. $R_{\mathrm{f}}$ : $0.1\left(\mathrm{SiO}_{2}\right.$; petroleum ether:EtOAc, 7:3). Mp: $185{ }^{\circ} \mathrm{C} .{ }^{1} \mathrm{H}$ NMR $\left(300 \mathrm{MHz}, \mathrm{CDCl}_{3}\right): \delta=3.85(\mathrm{~s}, 6 \mathrm{H}), 6.92-6.98(\mathrm{~m}, 5 \mathrm{H}), 7.07(\mathrm{~d}$, $\left.{ }^{3} J=5.1 \mathrm{~Hz}, 1 \mathrm{H}\right), 7.14\left(\mathrm{~d},{ }^{3} J=15.9 \mathrm{~Hz}, 1 \mathrm{H}\right), 7.56-7.62(\mathrm{~m}, 4 \mathrm{H}), 7.85\left(\mathrm{~d},{ }^{3} J=15.9 \mathrm{~Hz}, 1 \mathrm{H}\right)$, $7.99\left(\mathrm{~d},{ }^{3} J=15.9 \mathrm{~Hz}, 1 \mathrm{H}\right), 8.60\left(\mathrm{~d},{ }^{3} J=5.1 \mathrm{~Hz}, 1 \mathrm{H}\right) \mathrm{ppm} .{ }^{13} \mathrm{C}$ NMR $\left(75 \mathrm{MHz}, \mathrm{CDCl}_{3}\right): \delta=$ $55.47,55.49,114.4,114.5,115.3,124.1,125.8,128.7,129.1,129.2,129.3,136.7,137.5$, $157.3,160.5,160.8,162.8,165.1 \mathrm{ppm}$. IR (ATR): $v=2964,1560,1250,1177,1028,972$ $826 \mathrm{~cm}^{-1}$. HR-MALDI-MS (DCTB): $\mathrm{m} / \mathrm{z}$ calculated for $\mathrm{C}_{22} \mathrm{H}_{21} \mathrm{~N}_{2} \mathrm{O}_{2}\left[(\mathrm{M}+\mathrm{H})^{+}\right] 345.1598$, found 345.1592 .

(E,E)-2,4-Bis(4-dimethylaminostyryl)pyrimidine (7c). Synthesized from 6 c (41 mg, 0.17 mmol) and 4-N,N-dimethylaminobenzaldehyde (26 mg, $0.17 \mathrm{mmol})$ following the general procedure for Knoevenagel condensation. The crude product was purified by recrystallization from $\mathrm{CH}_{2} \mathrm{Cl}_{2} / n$-heptane. Yield: $55 \mathrm{mg}(85 \%)$; brown solid. $R_{\mathrm{f}}$ : $0.2\left(\mathrm{SiO}_{2}\right.$; petroleum ether:EtOAc, 8:2). Mp: $243{ }^{\circ} \mathrm{C} .{ }^{1} \mathrm{H}$ NMR (300 MHz, $\left.\mathrm{CDCl}_{3}\right): \delta=3.02-3.03$ (m, 12H), 6.70$6.74(\mathrm{~m}, 4 \mathrm{H}), 6.88\left(\mathrm{~d},{ }^{3} J=15.9 \mathrm{~Hz}, 1 \mathrm{H}\right), 7.01-7.09(\mathrm{~m}, 2 \mathrm{H}), 7.51-7.57(\mathrm{~m}, 4 \mathrm{H}), 7.80\left(\mathrm{~d},{ }^{3} J=\right.$ $15.9 \mathrm{~Hz}, 1 \mathrm{H}), 7.96\left(\mathrm{~d},{ }^{3} J=15.9 \mathrm{~Hz}, 1 \mathrm{H}\right), 8.54\left(\mathrm{~d},{ }^{3} J=5.1 \mathrm{~Hz}, 1 \mathrm{H}\right) \mathrm{ppm} .{ }^{13} \mathrm{C} \mathrm{NMR}(75 \mathrm{MHz}$, $\left.\mathrm{CDCl}_{3}\right): \delta=40.4,40.5,112.2,112.3,114.3,121.7,123.4,124.1,124.6,129.2,129.3,137.3$, 138.0, 151.1, 151.3, 156.9, 163.3, 165.5 ppm. IR (ATR): $v=2920,1602,1550,1520,1359$, 1163, 970, 810, $781 \mathrm{~cm}^{-1}$. HR-MALDI-MS (DCTB): $\mathrm{m} / \mathrm{z}$ calculated for $\mathrm{C}_{24} \mathrm{H}_{26} \mathrm{~N}_{4}\left[\mathrm{M}^{+}\right]$ 370.2152 , found 370.2150 .

(E,E)-2,4-Bis(4-diphenylaminostyryl)pyrimidine (7d). Synthesized from 6d (76 mg, 0.21 mmol) and 4-N,N-diphenylaminobenzaldehyde $(58 \mathrm{mg}, 0.21 \mathrm{mmol})$ following the general procedure for Knoevenagel condensation. The crude product was purified by recrystallization 
from $\mathrm{CH}_{2} \mathrm{Cl}_{2} / n$-heptane. Yield: $51 \mathrm{mg}$ (39\%); yellow solid. $R_{\mathrm{f}}$ : 0.3 ( $\mathrm{SiO}_{2}$; petroleum ether:EtOAc, 8:2). $T_{\mathrm{d}}: 250{ }^{\circ} \mathrm{C} .{ }^{1} \mathrm{H}$ NMR $\left(300 \mathrm{MHz}, \mathrm{CDCl}_{3}\right): \delta=6.92-6.97(\mathrm{~m}, 2 \mathrm{H}), 7.04-$ $7.15(\mathrm{~m}, 19 \mathrm{H}), 7.29-7.32(\mathrm{~m}, 6 \mathrm{H}), 7.46-7.52(\mathrm{~m}, 4 \mathrm{H}), 7.82\left(\mathrm{~d},{ }^{3} J=15.9 \mathrm{~Hz}, 1 \mathrm{H}\right), 7.97\left(\mathrm{~d},{ }^{3} J\right.$ $=15.9 \mathrm{~Hz}, 1 \mathrm{H}), 8.59\left(\mathrm{~d},{ }^{3} J=5.4 \mathrm{~Hz}, 1 \mathrm{H}\right) \mathrm{ppm} .{ }^{13} \mathrm{C} \mathrm{NMR}\left(75 \mathrm{MHz}, \mathrm{CDCl}_{3}\right): \delta=115.1,122.5$, $122.7,123.6,123.8,124.1,125.2,125.3,125.9,128.78,128.82,129.3,129.5,129.6,130.0$, $136.7,137.5,147.3,147.4,148.8,149.1,157.2,162.9,165.1$ ppm. IR (ATR): $v=3034,2924$, 1588, 1556, 1490, 1274, 1174, 972, 831, 751, $693 \mathrm{~cm}^{-1}$. HR-MALDI-MS (DCTB): m/z calculated for $\mathrm{C}_{44} \mathrm{H}_{34} \mathrm{~N}_{4}\left[\mathrm{M}^{+}\right]$618.2778, found 618.2779.

\section{Associated contents}

The supporting information is available free of charge on the ACS Publications website at doi:

Experimental and calculated absorption spectra in dichloromethane as well as correlation between experimental and emission maxima for $\mathbf{A}_{\mathbf{3}}, \mathbf{2} \mathbf{g}, \mathbf{2} \mathbf{j}, \mathbf{2} \mathbf{m}, \mathbf{2} \mathbf{k}$, cartesian coordinates, total energies for $\mathbf{A} \mathbf{3}, \mathbf{2 g}, \mathbf{2} \mathbf{j}, \mathbf{2} \mathbf{m}, \mathbf{2} \mathbf{k}$ emission maxima $\left(\lambda_{e m}\right) v s \mathrm{E}_{\mathrm{T}}(30)$ for compounds $\mathbf{2 b}-\mathbf{g}$, 2i-s, 5a-b, 7c-d, DSC curves of chromophores 2, 5, 7, A2 and A3, ${ }^{1} \mathrm{H}$ and ${ }^{13} \mathrm{C}$ NMR spectra for compounds $\mathbf{1 - 7}$, ORTEP drawing of the chromophore $\mathbf{2 h}$ with thermal ellipsoid at $50 \%$ (pdf).

X-ray crystallographic data of compound $\mathbf{2 h}$ (CIF)

\section{Conflicts of interest}

There are no conflict to declare.

\section{Acknowledgements}

M. F. thanks the Région Bretagne, France for funding. 


\section{References}

1 (a) Achelle, S.; Rodríguez-López, J.; Robin-le Guen, F. Photoluminescence Properties of Aryl-, Arylvinyl-, and Arylethynylpyrimidine Derivatives. Chem. Select 2018, 3, 1852-1886;

(b) Achelle, S. Plé, N. Pyrimidine Ring as Building Block for the Synthesis of Functionalized П-Conjugated Materials. Curr. Org. Synth. 2013, 9, 163-187.

2 (a) Nakao, K.; Sasabe, H.; Komatsu, R.; Hayasaka, Y.; Ohsawa, T.; Kido, J. Unlocking the Potential of Pyrimidine Conjugate Emitters to Realize High-Performance Organic LightEmitting Devices. Adv.Opt.Mater. 2017, 5, 1600843; (b) Komatsu, R.; Sasabe, H.; Seino, Y.; Nakao, K.; Kido, J. Light-Blue Thermally Activated Delayed Fluorescent Emitters Realizing a High External Quatum Efficiency of 25\% and Unprecedented Low Drive Voltages in OLEDs. J.Mater. Chem.C 2016, 4, 2274-2278; (c) Wu, K.; Zhang, T.; Zhan, L.; Zhong, C.; Gong, S.; Jiang, N.; Lu, Z.-H.; Yang, C. Optimizing Optoelectronic Properties of Pyrimidine-Based TADF Emitters by Changing the Substituent for Organic Light-Emitting Diodes with External Quantum Efficiency Close to 25\% and Slow Efficiency Roll-Off. Chem.Eur.J. 2016, 22, 10860-10866; (d) Komatsu, R.; Ohsawa, T.; Sasabe, H.; Nakao, K.; Hayasaka, Y.; Kido, J. Manipulating the Electronic Excited State Energies of Pyrimidine-Based Thermally Activated Dealyed Fluorescence Emitters To Realize Efficient Deep-Blue Emission. ACS Apnl.Mater.Interfaces 2017, 9, 4742-4749; (e) R. Komatsu, H. Sasabe, J. Kido, J. Photon. Energy 2018, 8, 032108.

3 (a) Li, L.; Ge, J.; Wu, H.; Xu, Q.-H.; Yao, S. Q. Organelle-Specific Detection of Phosphatase Activities with Two-Photon Fluorogenic Probes in Cells and Tissues. J. Am. Chem.Soc. 2012, 134, 12157-12167; (b) Na, Z.; Li, L.; Uttamchandani, M.; Yao, S. Q. Microarray-Guided Discovery of Two-Photon (2P) Small Molecule Probes For Live-Cell Imaging of Cysteinyl Cathepsin Activities. Chem.Commun. 2012, 48, 7304-7306; (c) Zhang, 
Q.; Tian, X.; Hu, Z.; Brommesson, C.; Wu, J.; Zhou, H.; Yang, J.; Sun, Z.; Tian, Y.; Uvdal,

K. Nonlinear Optical Response and Two-Photon Biological Applications of a New Family of Imidazole-Pyrimidine Derivatives. Dves Pigm. 2016, 126, 286-295; (d) Liu, B.; Zhang, H.-L.; Liu, J.; Zhao, Y.-D.; Luo, Q.-M.; Huang, Z.-L. Novel Pyrimidine-Based Amphiphilic Molecules: Synthesis, Spectroscopic Properties and Applications in Two-Photon Fluorescence Microscopic Imaging. L.Mater. Chem. 2007, 17, 2921-2929.

4 Malval, J.-P.; Achelle, S.; Bodiou, L.; Spangenberg, A.; Gomez, L. C.; Soppera, O.; Robinle Guen, F. Two-Photon Absorption in a Conformationally Twisted D- $\pi$-A Oligomer: a Synergic Photosensitizing Approach For Muultiphoton Lithography. J. Mater. Chem. C 2014, 2, 7869-7880.

5 (a) Achelle, S.; Nouira, I.; Pfaffinger, B.; Ramondenc, Y.; Plé, N.; Rodríguez-López, J. VShaped 4,6-Bis(arylvinyl)pyrimidine Oligomers: Synthesis and Optical Properties. J. Org. Chem. 2009, 74, 3711-3717; (b) Tang, R.; Wang, X.; Zhang, W.; Zhuang, X.; Bi, S.; Zhang, W.; Zhang, F. Aromatic Azaheterocycle-Cored Luminogens With Tunable Physical Properties via Nitrogen Atoms For Sensing Strong Acids. J.Mater. Chem.C 2016, 4, 7640 7648.

6 (a) Hadad, C.; Achelle, S.; López-Solera, I.; García-Martínez, J. C.; Rodríguez-López, J. Metal Cation Complexation Studies of 4-Arylvinyl-2,6-di(pyridin-2-yl)pyrimidines: Effect on the Optical Properties. Dves Piom. 2013, 97, 230-237; (b) Weng, J.; Mei, Q.; Ling, Q.; Fan, Q.; Huang, W. A New Colorimetric and Fluorescent Ratiometric Sensor for $\mathrm{Hg} 2+$ Based on 4-Pyren-1-yl-pyrimidine. Tetrahedron, 2012, 68, 3129-3134.

7 (a) Verbitskiy, E. V. Baranova, A. A.; Lugovik, K. I.; Shafikov, M. Z.; Khokhlov, K. O.; ECheprakova, E. M.; Rusinov, G. L.; Chupakhin, O. N.; Charushin, V. N. Detection of Nitroaromatic Explosives by new D- $\pi$-A Sensing Fluorophores on the Basis of the Pyrimidine Scafold. Anal. Bioanal. Chem. 2016, 408, 4093-4101; (b) Verbitskiy, E. V.; Baranova, A. A.; 
Lugovik, K. I.; Khokhlov, K. O.; Cheprakova, E. M.; Shafikov, M. Z.; Rusinov, G. L.; Chupakhin, O. N.; Charushin, V. N. New 4,5-Di(hetero)arylpyrimidines as Sensing Elements for Detection of Nitroaromatic Explosives in Vapor Phase. Dves Pigm. 2017, 137, 360-371.

8 Boländer, A.; Kiesser, D.; Voss, C.; Bauer, S.; Schön, C.; Burgold, S.; Bittner, T.; Hölzer, J.; Heyny-von Haußen, R.; Mall, G.; Goetschy, V.; Czech, C.; Knust, H.; Berger, R.; Herms, J.; Hilger, I.; Schmidt, B. Bis(arylvinyl)pyrazines, -pyrimidines, and -pyridazines As Imaging Agents for Tau Fibril and $\beta$-Amyloid Plaques in Alzheimer's Disease Models. J. Med. Chem. 2012, 55, 9170-9180.

9 (a) Achelle, S.; Rodríguez-López, J.; Katan, C.; Robin-le Guen, F. Luminescence Behavior of Protonated Methoxy-Substituted Diazine Derivatives: Toward White Light Emission. J. Phvs. Chem.C 2016, 120, 26986-26995; (b) Liu, D.; Zhang, Z.; Zhang, H.; Wang, Y. A Novel Approach Towards White Photoluminescence and Electroluminescence by Controlled Protonation of a Blue Fluorophore. Chem. Commun. 2013, 49, 10001-10003.

10 Kato, S.-i.; Yamada, Y.; Hiyoshi, H.; Umezu, K.; Nakamura, Y. Series of CarbazolePyrimidine Conjugates: Syntheses and Electronic, Photophysical, and Electrochemical Properties. L. Org Chem. 2015, 80, 9076-9090.

11 (a) Klikar, M.; Solanke, P.; Tydlitát, J.; Bureš, F. Alphabet-Inspired Design of (Hetero)Aromatic Push-Pull Chromophores. Chem. Rec. 2016, 6, 1886-1905; (b) Detert, H.; Lehmann, M.; Meier, H. Star-Shaped Conjugated Systems. Materials 2010, 3, 3218-3330.

12 (a) Meier, H.; Holst, H. C.; Oehlhof, A. Star-Shaped Compounds Having 1,3,5-Triazine Cores. Eur. J. Org. Chem. 2003, 4173-4180; (b) Meier, H.; Karpouk, E.; Holst, H. C. StarShaped Push-Pull Compounds Having 1,3,5-Triazine Cores. Eur. J. Org. Chem. 2006, 26092617; (c) Jiang, Y.; Wang, Y.; Wang, B.; Yang, J.; He, N.; Qian, S.; Hua, J. Synthesis, TwoPhton Absorption and Optical Limiting Properties of Multi-branched Styryl Derivatives Based on 1,3,5-Triazine. Chem.Asian J. 2011, 6, 157-165; (d) Wang, Y.; Jiang, Y.; Liu, D.; 
Wang, Y.; Wang, G.; Hua, J. Ultrafast Relaxation Processes of Multi-Branched Compounds Based on 1,3,5-Triazine: An Investigation of the Causes of a High Fluorescence Quantum Yield After Modification With Perfluoroalkyl Chains. J. Lumin. 2017, 190, 89-93.

13 Brunel, J.; Mongin, O.; Jutand, A.; Ledoux, I.; Zyss, J.; Blanchard-Desce, M. PropellerShaped Octupolar Molecules Derived From Triphenylbenzene For Nonlinear Optics: Synthesis and Optical Studies. Chem. Mater. 2003, 15, 4139-4148.

14 (a) Terenziani, F.; Le Droumaguet, C.; Katan, C.; Mongin, O.; Blanchard-Desce, M. Effect of Branching on Two-Photon Absorption in Triphenylbenzene Derivatives. ChemPhysChem 2007, 8, 723-734; (b) Terenziani, F.; Katan, C.; Badaeva, E.; Tretiak, S.; Blanchard-Desce, M. Enhanced Two-Photon Absorption of Organic Chromophores: Theoretical and Experimental Assessments. Adv. Mater. 2008, 20, 4641-4678.

15 (a) Itami, K.; Yamazaki, D.; Yoshida, J.-i. Pyrimidine-Core Extended $\pi$-Systems: General Synthesis and Interesting Fluorescent Properties. J.Am. Chem. Soc. 2004, 126, 15396-15397; (b) Achelle, S.; Ramondenc, Y.; Marsais, F.; Plé, N. Star- and Banana-Shaped Oligomers with a Pyrimidine Core: Synthesis and Light-Emitting Properties. Eur. J. Org. Chem. 2008, 31293140; (c) Muraoka, H.; Obara, T.; Ogawa, S. Systematic Syntesis, Comparative Studies of the Optical Properties, And the ICT-Based Sensor Properties of a Series of 2,4,6-Tri(5-aryl-2thienyl)pyrimidines with the D- $\pi$-A System. Tetrahedron Lett. 2016, 57, 3011-3015; (d) Bagley, M. C.; Lin, Z.; Pope, S. J. A. Barium Manganate in Microwave-Assisted Oxidation Reactions: Synthesis of Solvatochromic 2,4,6-Triarylpyrimidines. Tetrahedron Lett. 2009, 50, 6818-6822.

16 (a) Achelle, S.; Ramondenc, Y.; Dupas, G.; Plé, N. Bis- and Tris(arylethynyl)pyrimidine Oligomers: Synthesis and Light-Emitting Properties. Tetrahedron 2008, 64, 2783-2791; (b) Malik, I.; Ahmed, Z.; Reimann, S.; Ali, I.; Villinger, A.; Langer, P. Synthesis and Photophysical Properties of Alkynylated Pyrimidines by Site-Selective Sonogashira Reactions 
of 2,4,5,6-Tetrachloropyrimidine; First Synthesis of Tetraalkynyl-pyrimidines. Eur. J. Org. Chem. 2011, 2088-2093.

17 (a) Pascal, L.; Vanden Eynde, J.-J.; Van Haverbeke, Y.; Dubois, P.; Michel, A.; Rant, U.; Zojer, E.; Leising, G.; Van Dorn, L. O.; Gruhn, N. E.; Cornil, J.; Brédas, J.-L. Synthesis and Characterization of Novel para-and meta-Phenylenevinylene Derivatives: Fine Tuning of the Electronic and Optical Properties of Conjugated Materials. J.Phvs. Chem. B 2002, 106, 64426450. (b) Zhang, Q.; Luo, L.; Xu, H.; Hu, Z.; Brommesson, C.; Wu, J.; Sun, Z.; Tian, Y.; Uvdal, K. Design, Synthesis, Linear and Nonlinear Photophysical Properties of Novel Pyrimidine-Based Imidazole Derivatives. New J. Chem. 2016, 40, 3456-3463; (c) Li, L.; Tian, Y.-P.; Yang, J.-X.; Sun, P.-P.; Wu, J.-Y.; Zhou, H.-P.; Zhang, S.-Y.; Jin, B.-K.; Xing, X.-J.; Wang, C.-K.; Li, M.; Cheng, G.-H.; Tang, H.-H.; Huang, W.-H.; Tao, X.-T.; Jiang, M.-H. Facile Synthesis and Systematic Investigations of a Series of Novel Bent-Shaped Two-Photon Absorption Chromophores Based on Pyrimidine. Chem. Asian J. 2009, 4, 668-680.

18 (a) Achelle, S.; Robin-le Guen, F. 2-Arylvinylpyrimidines versus 4-Arylvinylpyrimidines: Synthesis and Comparison of the Optical Properties. Tetrahedron Lett. 2013, 54, 4491-4496; (b) Klikar, M.; le Poul, P.; Růžička, A.; Pytela, O.; Barsella, A.; Dorkenoo, K. D.; Robin-le Guen, F.; Bureš, F.; Achelle, S. Dipolar NLO Chromophores Bearing Diazine Rings as $\pi$ Conjugated Linkers. J.Org Chem. 2017, 82, 9435-9451.

19 (a) Akdas-Kilig, H.; Roisnel, T.; Ledoux, I.; Le Bozec, H. A New Class of BipyrimidineBased Octupolar Chromophores: Synthesis, Fluorescent and Quadratic Nonlinear Optical Properties. New J.Chem. 2009, 33, 1470-1473; (b) Savel, P.; Akdas-Kilig, H.; Malval, J.-P.; Spangenberg, A.; Roisnel, T.; Fillaut, J.-L. Metal-Induced Dimensionality Tuning in a Series of Bipyrimidine-Based Ligands: a Tool to Enhance Two-Photon Absorption. J. Mater. Chem. C 2014, 2, 295-305. 
20 (a) Molander, G. A.; Bernardi, C. R. Suzuki-Miyaura Cross-Coupling Reactions of Potassium Alkenyltrifluoroborates. J. Org. Chem. 2002, 67, 8424-8429; (b) Yamanaka, H.; Ogawa, S.; Konno, S. Studies on Pyrimidine-Derivatives .18. Reaction of active MethylGroups on Pyrimidine N-Oxides. Chem. Pharm. Bull. 1980, 28, 1526-1533.

21 (a) Zielinski,W. Preparation of Pyrimidines and Pyridines From Alkyl Ketones and Nitriles in Presence of Phosphoryl Chloride. Heterocvcles 1985, 23, 1639-1644; (b) Roberts, J. C. A Confirmation of the Structure of 2,6-Dimethyl-4-pyrimidinyl-methyl-lithium and Some Observations on the Condensation of 1,3-Diketones With Acetamide. J. Chem. Soc. 1952, 3065-3068; (c) Giordano, C.; Minisci, F.; Tortelli, V.; Vismara, E. Polar Effects on the Homolytic Methylation of Pyrimidine - Orientation and Polysubstitution. J. Chem. Soc. Perkin Trans. 2 1984, 293-295.

22 (a) Armstrong, R. J.; Smith, M. D. Catalytic Enantioselective Synthesis of Atropoisomeric Biaryls: A Cation-Derected Nucleophilic Aromatic Substitution Reaction. Angew. Chem. Int. Ed. 2014, 53, 12822-12826; (b) Harden, D. B.; Mokrosz, M. J.; Strekowski, L. Addition and Substitution Reactions of Chloropyrimidines With Lithium Reagents. J. Org. Chem. 1988, 53, 4137-4140.

23 Perner, R. J.; Lee, C.-H.; Jiang, M.; Gu, Y.-G.; DiDomenico, S.; Bayburt, E. K.; Alexander, K. M.; Kohlhaas, K. L.; Jarvis, M. F.; Kowaluk, E. L.; Bhagwat, S. S. Synthesis and Biological Evaluation of 6,7-Disubstituted 4-Aminopyrido[2.3-d]pyrimidines as Adenosine Kinase Inhibitors. Bioorg Med.Chem.Lett. 2005, 15, 2803-2807.

24 (a) Schomaker, J. M.; Delia, T. J. Arylation of Halogenated Pyrimidines via a Suzuki Coupling Reaction. J. Org. Chem. 2001, 66, 7125-7128; (b) Anderson, S. C.; Handy, S. T. One-Pot Double Suzuki Couplings of Dichloropyrimidines. Synthesis 2010, 221-2724; (c) Delia, T. J.; Schomaker, J. M.; Kalinda, A. S. The Synthesis of substituted Phenylpyrimidines via Suzuki Coupling Reactions. J.Heterocvcl. Chem. 2006, 43, 127-131. 
25 Tang, C.; Zhang, Q.; Li, D.; Zhang, J.; Shi, P.; Li, S.; Wu, J.; Tian, Y. Synthesis, Crystal Structures, Two-Photon Absorption and Biological Imaging Application of Two Novel BentShaped Pyrimidine Derivatives. Dves Pigm. 2013, 99, 20-28.

26 Eaton, D. F. Reference Materials for Fluorescence Measurement. Pure Appl. Chem. 1988, $60,1107-1114$.

27 Reichardt, C. Solvatochromic Dyes as Solvent Polarity Indicators. Chem. Rev. 1994, 94, 2319-2358.

28 (a) Lartia, R.; Alain, C.; Bordeau, G.; Schmidt, F.; Fiorini-Debuisschert, C.; Charra, F.; Teulade-Fichou, M.-P. Synthetic Strategies to Derivatizable Triphenylamine Displaying High Two-Photon Absorption. J. Org. Chem. 2008, 73, 1732-1744; (b) Katan, C.; Charlot, M.; Mongin, O.; Le Droumaguet, C.; Jouikov, V.; Terenziani, F.; Badaeva, E.; Tretiak, S.; Blanchard-Desce, M. Simultaneous Control of Emission Localization and Two-Photon Absorption Efficiency in Dissymmetrical Chromophores. J. Phys. Chem. B 2010, 114, 31523169; (c) Merkt, F. K.; Höwedes, S. P.; Gers-Panther, C. F.; Gruber, I.; Janiak, C.; Müller, T. J. J. Three-Component Activation/Alkynylation/Cyclocondensation (AACC) Synthesis of Enhanced Emission Solvatochromic 3-Ethynylquinoxalines. Chem.Eur.J. 2018, 24, 81148125; (d) Panthi, K.; Adhikari, R. M.; Kinstle, T. H. Aromatic Fumaronitrile Core-Based Donor-Linker-Acceptor-Linker-Donor (D-pi-A-pi-D) Compounds: Synthesisand Photophysical Properties. L. Phvs. Chem.A 2010, 114, 4542-4549.

29 Gaussian 16, Revision A.03, Frisch, M. J.; Trucks, G. W.; Schlegel, H. B.; Scuseria, G. E.; Robb, M. A.; Cheeseman, J. R.; Scalmani, G.; Barone, V.; Petersson, G. A.; Nakatsuji, H.; Li, X.; Caricato, M.; Marenich, A. V.; Bloino, J.; Janesko, B. G.; Gomperts, R.; Mennucci, B.; Hratchian, H. P.; Ortiz,J. V.; Izmaylov, A. F.; Sonnenberg, J. L.; Williams-Young, D.; Ding, F.; Lipparini, F.; Egidi, F.; Goings, J.; Peng, B.; Petrone, A; Henderson, T.; Ranasinghe, D.; Zakrzewski, V. G.; Gao, J.; Rega, N.; Zheng, G.; Liang, W.; Hada, M.; Ehara, M.; Toyota, K.; 
Fukuda, R.; Hasegawa, J.; Ishida, M.; Nakajima, T.; Honda, Y.; Kitao, O.; Nakai, H.; Vreven, T.; Throssell, K.; Montgomery Jr. J. A.; Peralta, J. E.; Ogliaro, F.; Bearpark, M. J.; Heyd, J. J.; Brothers, E. N.; Kudin, K. N.; Staroverov, V. N.; Keith, T. A.; Kobayashi, R.; Normand, J.; Raghavachari, K.; Rendell, A. P.; Burant, J. C.; Iyengar, S. S.; Tomasi, J.; Cossi, M.; Millam, J. M.; Klene, M.; Adamo, C.; Cammi, R.; Ochterski, J. W.; Martin, R. L.; Morokuma, K.; Farkas, O.; Foresman, J. B. and Fox, D. J. Gaussian, Inc., Wallingford CT, 2016.

30 (a) Klikar, M.; Kityk, I. V.; Kulwas, D.; Mikysek, T.; Pytela, O.; Bureš, F. Multipodal Arrangement of Push-Pull Chromophores: a Fundamental Parameter Affecting Their Electronic and Optical Properties. New J. Chem. 2017, 41, 1459-1472; (b) Klikar, M.; Seintis, K.; Polyzos, I.; Pytela, O.; Mikysek, T.; Almonasy, N.; Fakis, M.; Bureš, F. Star-Shaped Push-Pull Molecules with a Varied Number of Peripheral Acceptors: An Insight into Their Optoelectronic Features. ChemPhotoChem 2018, 2, 465-474; (c) Seintis, K.; Agathangelou, D.; Cvejn, D.; Almonasy, N.; Bureš, F.; Giannetas, V.; Fakis, M. Femtosecond to Nanosecond Studies of Octupolar Molecules and Their Quadrupolar and Dipolar Analogues. Phys. Chem. Chem. Phys. 2017, 19, 16485-16497.

31 Sakamoto, T.; Tanhji, K.-I.; Niitsuma, S.; Ono, T.; Yamanaka, H. Studies on Pyrimidine Derivatives .20. Synthetic Utility of Hydroxymethylpyrimidines and Related-Compounds. Chem. Pharm. Bull. 1980, 28, 3362-3368.

32 Stanek, J.; Caravatti, G.; Capraro, H.-G.; Furet, P.; Mett, H.; Schneider, P.; Regenass, U. S-Adenosylmethionine Decarboxylase Inhibitors - New Aryl and Heteroaryl Analogs of Methylglyoxal Bis(guanylhydrazone). J.Med. Chem. 1993, 36, 46-54. 